\title{
UMATILLA RIVER BASIN ANADROMOUS FISH HABITAT ENHANCEMENT PROJECT \\ 1995 ANNUAL REPORT
}

\author{
Prepared by: \\ R. Todd Shaw, Fish Habitat Biologist \\ Confederated Tribes of the Umatilla Indian Reservation \\ Department of Natural Resources \\ Fisheries Propam
}

Prepared for:

U. S. Department of Energy

Bonneville Power Administration

Environment, Fish and Wildlife

P.O. Box 3621

Portland. OR 97208-362 1

Project Number 87- 100-O 1

Contract Number DE-BI79-87BP35768

May 1996 


\begin{abstract}
ABSIRACT
During the 1995 - 96 project period, four new habitat enhancement projects were implemented under the Umatilla River Basin Anadromous Fish Habitat Enhancement Project by the Confederated Tribes of the Umatilla Indian Reservation (CIUIR) in the upper Umatilla River Basin. A total of 38,644 feet of high tensile smooth wire fencing was constructed along 3.6 miles of riparian corridor in the Meacham Creek Wildhorse Creek, Greasewood Creek, West Fork of Greasewood Creek and Mission Creek watersheds. Additional enhancements on Wildhorse Creek and the lower Greasewood Creek System included: 1) installation of 0.43 miles of smooth wire between river mile (RM) 10.25 and RM 10.5 Wildhorse Creek (fence posts and structures had been previously placed on this property during the 1994 - 95 project period), 2) construction of 46 sediment retention structures in stream channels and maintenance to 18 existing sediment retention structures between RM 9.5 and RM 10.25 Wildhorse Creek, and 3) revegetation of stream corridor areas and adjacent terraces with 500 pounds of native grass seed or close species equivalents and 5.000 native riparian shrub/tree species to assist in floodplain recovery, stream channel stability and filtering of sediments during high flow periods. U.S. Fish and Wildlife Service (USFWS), Bureau of Indian Affairs (BIA) and Environmental Protection Agency (EPA) funds were cost shared with Bonneville Power Administration (BPA) funds, provided under this project, to accomplish habitat enhancements.
\end{abstract}

Water quality monitoring continued and was expanded for temperature and turbidity throughout the upper Umatilla River Watershed. Survey of stream channel cross sections and photo documentation of riparian recovery within the project areas provided additional baseline data.

Physical habitat surveys were conducted on the lower 13 river miles of Wildhorse Creek and within the Greasewood Creek Project Area to characterize habitat quality and to quantify various habitat types by area. Survey efforts were coordinated with the CTUIR Umatilla Basin Natural Production Monitoring and Evaluation (UBNPME) Project.

Poor land use practices which have altered natural floodplain dynamics and significantly reduced or eliminated fisheries habitat, continued to be identified in the Mission Creek Subbasin. Compiled data is currently being incorporated into a data layer for a Geographic Information System (GIS) data base. This effort is being coordinated with the Natural Resource Conservation Service (NRCS).

Community outreach efforts and public education opportunities continued during the reporting period. 


\section{ACKNOWLEDGMENTS}

This project was funded by the Bonneville Power Administration. The Confederated Tribes of the Umatilla Indian Reservation thank Jerry Bauer and other Bonneville Power Administration personnel for their assistance. Thanks also to Leslie Spencer of the Bureau of Indian Affairs, Tim Bailey of the Oregon Department of Fish \& Wildlife, Ed Calame of the Umatilla National Forest, Steve Wille and Maureen Smith of the U.S. Fish \& Wildlife Service, Bob Adelman of the Natural Resource Conservation Service and Luise Langheinrich, Coordinator of the Umatilla Basin Watershed Council for technical input and assistance.

We would like to acknowledge cooperating landowners, Steve Filkins, Beverly Rothrock. Kent Rothrock. Bud Schmidtgall, Terry Schmidtgall. Bob Miller, Janet Miller, Lynn Walker, Virginia Whitacre, Sam Haynes, Frances Myers. John P. Adams, John W. Adams, Lois Hartley, Helen Morrison, Merna Tovey. Emmet Williams, Fawn Williams, Kathy Williams, Cecelia Bearchum, Brenda Bearchum, Theresa Johnson and Eleanor Houle, who supported our efforts and provided important background information on their properties in the project areas.

Thanks also to Confederated Tribes of the Umatilla Indian Reservation staff, whose cooperation and contributions are evident in this report. Special thanks to Ken Hall, David Wolf, Brian Conner, Aaron Jackson, Jeremy Wolf, Neil Alexander and Brian Thompson for the long hours performing office duties, monitoring habitat enhancements, and implementing and maintaining improvements in project areas, to Aaron Skirvin for assistance with Mission Creek Watershed planning and coordination, to Michael Purser for assistance in providing cost share opportunities, to Jeff Van Pelt and Tom Bailor for conducting cultural resource surveys, to Cheryl Van Pelt for much appreciated assistance in coordinating with landowners and preparing landowner agreements, to Julie Burke and Celeste Reeves for secretarial services and public relations preparations, to Gary James for support and guidance and to Joe Richards and Michelle Thompson for administration of this agreement.

Last, but not least, we wish to thank June Davis, Confederated Tribes of the Umatilla Indian Reservation Nursery Manager and Umatilla Salmon Corps participants for assistance with native revegetation efforts in project areas in the fall of 1995 and spring of 1996. 


\section{TABLE OF CONTENTS}

ABSTRACT $\ldots \ldots \ldots \ldots \ldots \ldots \ldots \ldots \ldots \ldots \ldots \ldots \ldots \ldots \ldots \ldots \ldots \ldots$

ACKNOWLEDGEMENTS $\ldots \ldots \ldots \ldots \ldots \ldots \ldots \ldots \ldots \ldots \ldots \ldots \ldots \ldots$. . . . . . . . . .

TABLE OF CONTENTS $\ldots \ldots \ldots \ldots \ldots \ldots \ldots \ldots \ldots \ldots \ldots \ldots \ldots \ldots$ iii

LIST OF FIGURES $\ldots \ldots \ldots \ldots \ldots \ldots \ldots \ldots \ldots \ldots \ldots \ldots \ldots \ldots \ldots \ldots$

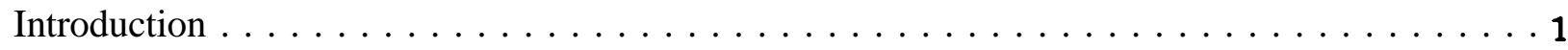

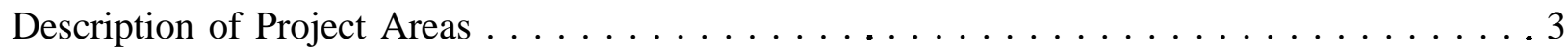

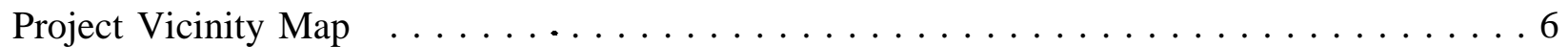

\section{METHODS AND MATERIALS}

Objective I. Maintain and Continue Implementation of Habitat Enhancement Projects throughout the Umatilla River Watershed.

1. Pre-construction Preparation

a. Assess Maintenance Needs . . . . . . . . . . . . . . . 7

b. BIA Right-of-Way Clearances and CIUIR Riparian Easements . . . . 7

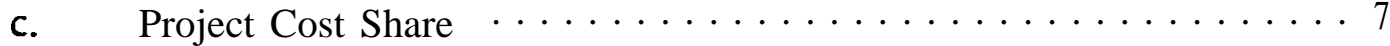

d. Fill and Removal Permits $\ldots \ldots \ldots \ldots \ldots \ldots \ldots \ldots$

On-site Cultural/Archeological Monitoring . . . . . . . . . . 8

. Design and Layout $\ldots \ldots \ldots \ldots \ldots \ldots \ldots \ldots \ldots$

g- Contracts........................ 8

h. High Tensile Fence Materials Purchase $\ldots \ldots \ldots \ldots \ldots \ldots \ldots$

i. Native Grasses, Riparian Shrubs and Trees $\ldots \ldots \ldots \ldots \ldots$

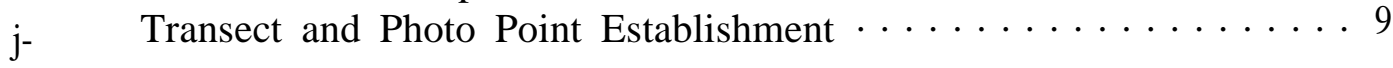

2. Maintain and Implement Habitat Enhancements

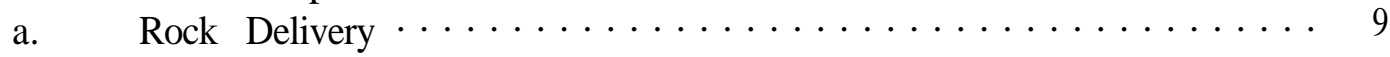

b. Contractor Supplies and Materials $\ldots \ldots \ldots \ldots \ldots \ldots \ldots \ldots$

c. Sediment Retention Structures . . . . . . . . . . . . . . . . 10

d. Instream and Bank Stabilization Maintenance . . . . . . . . . . 10

e. Livestock Exclusion and Riparian Corridor Fencing . . . . . . . . . 10

f. Construction Activities - Project Review and Inspection . . . . . . . 10

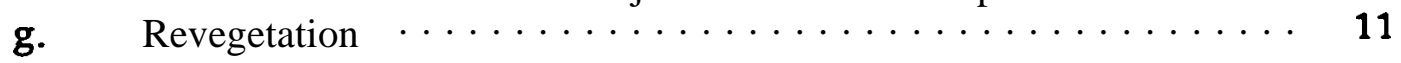


3. Post-construction Activities and Habitat Enhancement Monitoring

a. Post-construction Final Review . . . . . . . . . . . . . . . . 11

b. Transect Measurements and Photo Point Monitoring . . . . . . . . . 11

c. Physical Condition of Improvements and General Stream Hydraulics 12

Objective II. Collect Baseline Water Quality Data and Continue Post-project Monitoring to Identify Watershed Health Concerns and to Quantify the Short and Long-Term Effects of Habitat Enhancement Activities in the Umatilla River Basin.

1. Determine Existing Land Use Practices Impacting Salmon and Steelhead Habitat Capability

a Identification of Major Land Use Practices . . . . . . . . . . . . . . . 12

b: Identification of Site Specific Detrimental Land Use Practices . . . . . 12

2. Fish Habitat Surveys . . . . . . . . . . . . . . . . . . . . . . . . 12

3. Aquatic Macroinvertebrate Sampling .................. 13

4. Water Temperature Monitoring . . . . . . . . . . . . . . . . . . 13

5. Suspended Sediment Monitoring . . . . . . . . . . . . . . . . . . 14

Objective III. Continue Watershed Planning/Scoping/Education Process by Identifying Problems and Developing Creative Solutions to Land Use Problems Impacting Fisheries Habitat in the Umatilla River Basin.

1. Community Outreach Effort ...................... 15

2. Scoping Groups $\ldots \ldots \ldots \ldots \ldots \ldots \ldots \ldots \ldots \ldots \ldots \ldots$

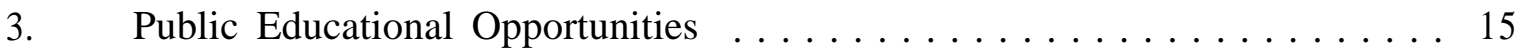

4. Public Monitoring Programs . . . . . . . . . . . . . . . . . . . . 16

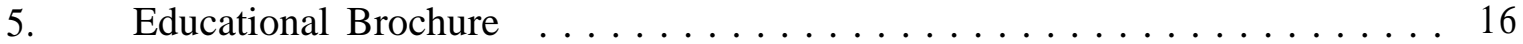

Objective IV. Pursue Alternative Management Methods to Mitigate Impacts from Past and Ongoing Land Management Activities

1. Acquisition Land/Management Rights . . . . . . . . . . . . . . . . . 16 


\section{RESULTS AND DISCUSSION}

Objective I. Maintain and Continue Implementation of Habitat Enhancement Projects throughout the Umatilla River Watershed.

1. Pre-construction Preparation

a. Assess Maintenance Needs . . . . . . . . . . . . . . . 17

b. BIA Right-of-Way Clearances and CIUIR Riparian Easements . . . 17

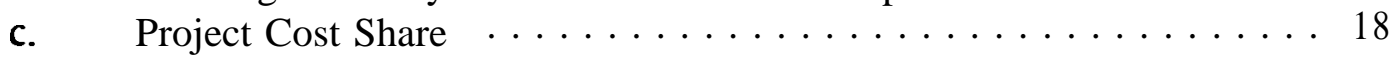

d. Fill and Removal Permits ................... 18

e. On-site Cultural/Archeological Monitoring . . . . . . . . . . . 18

f. Design and Layout . . . . . . . . . . . . . . . . . . . . . 19

g. Contracts............................. 19

h. High Tensile Fence Materials Purchase $\ldots \ldots \ldots \ldots \ldots \ldots \ldots$

i. Native Grasses, Riparian Shrubs and Trees ............. 20

j. Transect and Photo Point Establishment $\ldots \ldots \ldots \ldots \ldots \ldots \ldots$

2. Maintain and Implement Habitat Enhancements

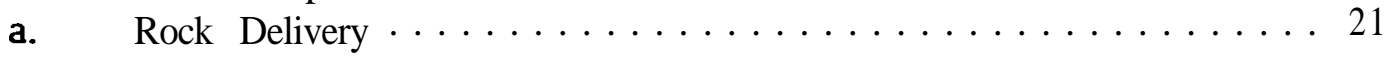

b. Contractor Supplies and Materials ................. 21

c. Sediment Retention Structures ................... 21

d. Instream and Bank Stabilization Maintenance ............. 22

e. Livestock Exclusion and Riparian Corridor Fencing . . . . . . . . 22

f. Construction Activities - Project Review and Inspection ........ 22



3. Post-construction Activities and Habitat Enhancement Monitoring

a. Post-construction Final Review ................ 23

b. Transect Measurements and Photo Point Monitoring .......... 24

c. Physical Condition of Improvements and General Stream Hydraulics 24

Objective II. Collect Baseline Water Quality Data and Continue Post-project Monitoring to Identify Watershed Health Concerns and to Quantify the Short and Long-Term Effects of Habitat Enhancement Activities in the Umatilla River Basin.

1. Determine Existing Land Use Practices Impacting Salmon and Steelhead Habitat Capability

a. Identification of Major Land Use Practices . . . . . . . . . . . . . 24

b. Identification of Site Specific Detrimental Land Use Practices . . . . 25

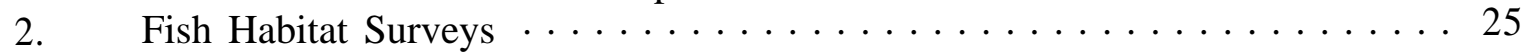

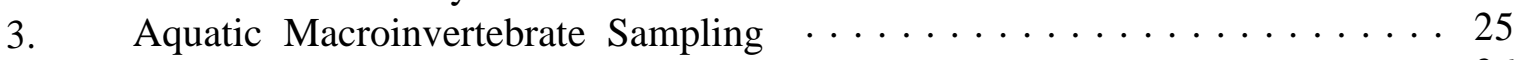

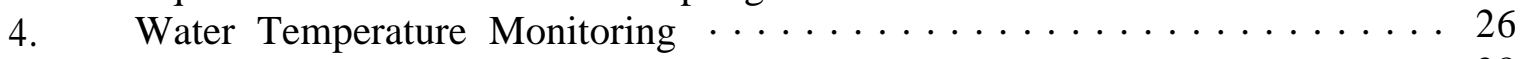

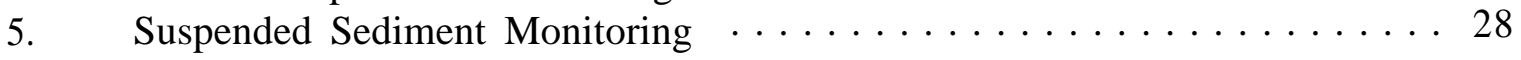


Objective III. Continue Watershed Planning/Scoping/Education Process by Identifying Problems and Developing Creative Solutions to Land Use Problems Impacting Fisheries Habitat in the Umatilla River Basin.

1. Community Outreach Effort . . . . . . . . . . . . . . . . . . . . 29

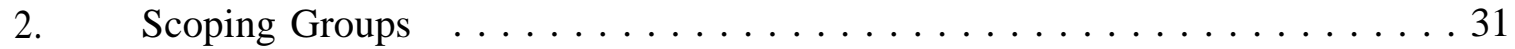

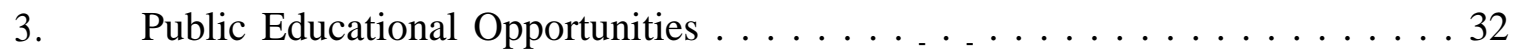

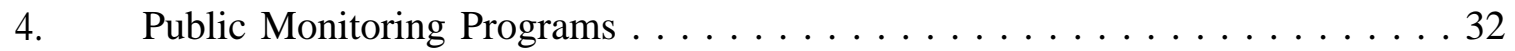

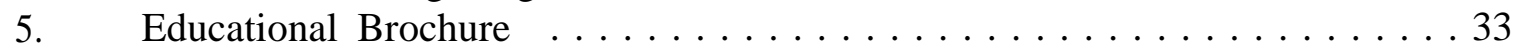

Objective IV. Pursue Alternative Management Methods to Mitigate Impacts from Past and Ongoing Land Management Activities

1. Acquisition Land/Management Rights . . . . . . . . . . . . . 33

Literature Cited ............................... 34

Appendix A. Water Temperature Graphs .................. 35

A-1. $\quad$ Umatilla River - River Mile 78.5 (Downstream Mouth of Meacham Creek)

A-2. Umatilla River - River Mile 79 (Upstream Mouth of Meacham Creek)

A-3. Umatilla River - River Mile 81.7 (USGS Gage Station No. 14020000)

A-4. Wildhorse Creek - River Mile 0 (Confluence with Umatilla River)

A-5. Wildhorse Creek - River Mile 9.5 (Upstream Mouth of Greasewood Creek)

A-6. Wildhorse Creek - River Mile 26

A-7. Mission Creek - River Mile 3.7 (Downstream of Stream Forks)

A-8. Buckaroo Creek - River Mile 2

A-9. Squaw Creek - River Mile 2

A-10. Squaw Creek - River Mile 9 (Confluence with Little Squaw Creek)

A-11. Meacham Creek - River Mile 2 (USGS Gage Station No. 14020300)

A-12. Meacham Creek - River Mile 5.25 (East Reservation Boundary)

Appendix B - Suspended Sediment Graphs . . . . . . . . . . . . . . 36

B-1. Umatilla River - River Mile 56

B-2. $\quad$ Umatilla River - River Mile 81.7 (USGS Gage Station No. 14020000)

B-3. Meacham Creek - River Mile 2 (USGS Gage Station No. 14020300) 


\section{LIST OF FIGURES}

1. CI'UIR Anadromous Fish Habitat Enhancement Project Vicinity Map $\ldots \ldots \ldots$

2. Thermograph Locations for 1995-96 Project Period . . . . . . . . . . . 14

3. Suspended Sediment Monitoring Sites for the 1995 Annual Year . . . . . . . 15 


\section{INTRODUCTION}

The Umatilla Basin Anadromous Fish Habitat Enhancement Project is funded under the Northwest Power Planning Council's Columbia River Basin Fish and Wildlife Program, Section 7.6 - 7.8 and targets the improvement of water quality and restoration of riparian areas, and specifically the holding, spawning and rearing habitats of salmonids. Funding of this project provides partial mitigation for losses of salmon and steelhead populations in the Columbia River Basin from the construction and operation of hydroelectric dams. This Umatilla River Basin Anadromous Fish Habitat Enhancement Project Report covers work accomplished by the Confederated Tribes of the Umatilla Indian Reservation from May 1,1995 through April 30,1996 as part of the Umatilla Basin Fisheries Restoration Program.

Significant effort and funds have been directed at restoration of anadromous fish in the Umatilla River Basin. This habitat project is one element in the comprehensive Umatilla Basin Fisheries Restoration Program which also includes artificial production, adult and juvenile passage improvements (ladders, screens and trap and haul), instream flow enhancement and monitoring and evaluation. Emphasis on watershed-wide habitat is needed for protection and enhancement of the natural production capabilities in the basin.

The primary problems continuing to impact water quality and limit available habitat and natural fisheries production capabilities in the Umatilla River Basin include: non-point source pollution due to poor cropland tillage and rotation practices, livestock overgrazing riparian and upland areas, over appropriation of necessary instream flows to irrigators, and stream channelization, constriction, and floodplain modification from agricultural and road/railroad building and maintenance activities.

The project focused on implementing cooperative instream and riparian habitat improvements on private lands on the Umatilla Indian Reservation (hereafter referred to as Reservation) from April 1. 1988 to March 31, 1992. These efforts resulted in enhancement of the lower 1/4 mile of Boston Canyon Creek, the lower 4 river miles of Meacham Creek and 3.2 river miles of the Umatilla River in the vicinity of Gibbon, Oregon. In 1993, the project shifted emphasis to a comprehensive watershed approach, consistent with other basin efforts, and began to identify upland and riparian watershed-wide causative factors impacting fisheries habitat and natural fisheries production capabilities throughout the Umatilla River Watershed. An additional 4.5 river miles of fisheries habitat improvement projects have been implemented on private properties, both on and off the Reservation since shifting to a watershed approach. Additional

projects have included habitat enhancements in the Meacham Creek, Mission Creek, Wildhorse Creek and Greasewood Creek drainages. 
The project represents a continuation and evolution of existing efforts to improve natural production in the Umatilla River Basin. Land use practices in the watershed and existing fish and riparian habitats are being analyzed to identify and address the watershed-wide causative factors to reduced fish production capability. The project will continue to provide critical elements to a comprehensive watershed management approach to help guide implementing agencies including CIUIR in promoting anadromous fish rebuilding plans, and recommend necessary changes to management systems.

Technical integration and coordination is being provided by utilizing a GIS data base for such components as habitat condition, land ownership, land use, ecotype and proposed management/restoration actions. The project complements ongoing fish passage and artificial production projects already in place in the basin and will integrate existing on-the-ground management systems and programs on private and public lands with restoration activities to better justify expenditure of funds and time. Stream habitat surveys, summaries of existing survey information and follow up surveys are coordinated with CIUIR's UBNPME Project. Remedial measures will be implemented to reduce or eliminate detrimental land use activities where possible. Continued operations and maintenance of existing enhancement projects are included under this integrated approach.

The restoration of anadromous fisheries resources in the Umatilla River Basin has been a coordinated effort between CIUIR. local, state and federal agencies and the agricultural community. Examples include the Umatilla River Basin Anadromous Fish Habitat Enhancement Project, the Umatilla Basin Project, the Umatilla River Subbasin Salmon and Steelhead Production Plan and development of the Umatilla Hatchery and associated artificial production plans. This coordination will continue and expand through scoping groups comprised of local land owners. sportsman clubs and resource agencies formed to identify issues and develop creative solutions to land use problems in the basin. 


\section{DESCRIPTION OF PROJECT AREAS}

Project areas include the Umatilla River between RM 78.5 and RM 82.7, the lower 4.5 miles of Meacham Creek, the lower 1/4 mile of Boston Canyon Creek Wildhorse Creek between RM 9.5 to RM 10.5 and RM 11.5 to RM 12.5. the lower 1.5 miles of Greasewood Creek, the lower 1/4 mile of the West Fork of Greasewood Creek, and Mission Creek between RM 2.9 and RM 3.3.

The Umatilla River is a tributary to the Columbia River at RM 289. It has a drainage basin of 308 square miles below the confluence of Meacham Creek. The principle aquifer is quaternary alluvium composed of unconsolidated sand and gravel, and some silt. Alluvium may reach a depth of up to 12 feet (Gonthier and Harris, 1977).

Meacham Creek is a major tributary to the Umatilla River, entering at RM 79. It drains approximately 165 square miles and produces 145.000 acre-feet annually at RM 5 near the head of the project area.

Boston Canyon Creek, entering Meacham Creek at RM 2.1, is the largest tributary to Meacham Creek within Reservation Boundaries. It contributes over 4,000 acre-feet annually to Meacham Creek from a drainage basin of approximately 5.5 square miles. It runs over and through large alluvial deposits as it enters the Meacham Creek floodplain.

Elevations in the Umatilla River, Meacham Creek and Boston Canyon Creek project areas range from 1,760 to 2,000 feet above sea level, giving the area an unusually long growing season. Stream gradients average less than two percent. Flooding in the project area usually occurs in late winter and spring as a result of a rain on snow event. The flood peaks tend to be high and the volumes large, but the duration of damaging stages seldom last more than a day or two (U.S. Army Corps of Engineers, 1975).

The Umatilla River, Meacham Creek and Boston Canyon Creek project areas lie in a big game winter grazing zone as outlined by the CTUIR Land Development Code (1983). The primary land use is livestock grazing from May to November. Timber harvest is permissible under a conditional use permit.

Wildhorse Creek is a 34 mile intermittent tributary to the Umatilla River, entering at RM 55 in the city of Pendleton. Oregon. It drains approximately 190 square miles and produces 14,000 acre-feet annually at the mouth. The highest point on the drainage divide of the basin is at an altitude of about 3,800 feet (Gonthier and Harris, 1977). A steep headwater topography of 15 to 35 percent contributes to rapid runoff rates. The slope in the lower and mid reaches varies from 0 to 3 percent (U.S. Department of Agriculture, Soil Conservation Service, 1988).

Riparian and water storage capabilities in the upper Wildhorse Creek Watershed have been impacted from past timber harvest practices. Mid and low elevation lands are characterized by dryland crop farming. livestock grazing and residential use. Poor land use practices have significantly impacted upland vegetation communities, reduced riparian vegetation. degraded 
water quality, and diminished water table elevations and instream flows. Lack of conservation farming practices, such as strip cropping, terrace systems and grass waterways, are common problems in mid and lower watershed areas. Overgrazing of livestock and absence of pasture rotation plans have contributed to poor water quality and loss of flood plain function. The communities of Athena and Adams, county and state highway departments and the Union Pacific Railroad have constrained the mainstem stream channel, resulting in downcutting, loss of flood plain function and water quality impacts.

Greasewood Creek originates approximately 3.25 miles northwest of the town of Helix and flows southeast to enter Wildhorse Creek at RM 9.3, 1/2 mile downstream of the Blakely Gram Elevator. The West Fork of Greasewood Creek originates 1.75 miles southwest of Helix and enters mainstem Greasewood Creek 1.5 mile upstream of the Wildhorse Creek confluence. The Greasewood Creek Watershed drains approximately 20.452 acres over a 33 square mile area. Annual precipitation ranges from 12 to 15 inches per year with $70 \%$ of this moisture being obtained during October through April. Stream flows in mid and upper watershed areas are intermittent during summer and early fall months. However, in the lower watershed springs provide year-round flows to the Greasewood Creek and West Fork Greasewood Creek project areas. A recent study conducted by NRCS estimated the ten year peak flow in the upper 9,650 acres of the watershed (upstream of State Highway 334) at 143 cfs (Ray Wilson, personal communication). Elevations in the watershed range from 1,800 feet above sea level in the headwaters to 1,400 feet above sea level at the confluence with Wildhorse Creek Soils throughout the drainage are predominantly Walla Walla Series, consisting of deep, well-drained silt loams on 1 to 40 percent slopes.

NRCS personnel estimate that $98 \%$ of landuse in the Greasewood Creek Watershed is comprised of cropland practices, primarily winter wheat/summer fallow operations (Ray Wilson, personal communication). The deep soils in this drainage are considered to be some of the most productive agricultural soils in the Umatilla River Basin. However, lack of terraces, grass waterways and contour farming practices, failure to return crop residue to the soil and farming in highway right-of-way areas results in extensive erosion of top soils from steep slopes into roadside ditches and waterways. NRCS staff estimate as much as 130 tons/acre of top soil erodes annually from cropland fields in the Greasewood Creek Watershed (Bob Adelman, personal communication).

Mission Creek originates in the western slope foothills of the Blue Mountain Range at an elevation of about 3,560 feet and flows northwesterly to empty into the Umatilla River at approximately RM 61.5 at an elevation of about 1.270 feet. The watershed is located entirely within Reservation Boundaries and has a total acreage of approximately 3,100 acres. The watershed is comprised of the following landuse practices: 1) 2.100 acres of rangeland, 2) 670 acres of winter wheat/summer fallow cropland, 3) 180 acres of Conserrration Reserve Program (CRP) land, 4) 140 acres of abandoned cropland and 5) 10 acres of residential property. Average annual precipitation ranges from 16 to 24 inches with most of it falling between October and March as rain. Mission Creek is an intermittent stream with stream flows in the lower reaches and portions of the upper watershed going subsurface by mid-summer. 
Conversion of historical, native plant communities to cropland and rangeland combined with realignment and shortening of lower stream channel reaches has altered the hydrologic capabilities of the Mission Creek Watershed. resulting in higher peak runoff rates during storm events, increased channel/streambank erosion and loss of fish and wildlife habitat. Limited portions of the mid watershed sustain year-round stream flows and provide excellent salmonid habitat. Lack of perennial stream flows and insufficient riparian cover are the primary factors limiting anadromous fisheries production in this system.

A map of the Umatilla River, Meacham Creek, Boston Canyon Creek, Wildhorse Creek, Greasewood Creek/West Fork of Greasewood Creek and Mission Creek project areas is illustrated in Figure 1. 


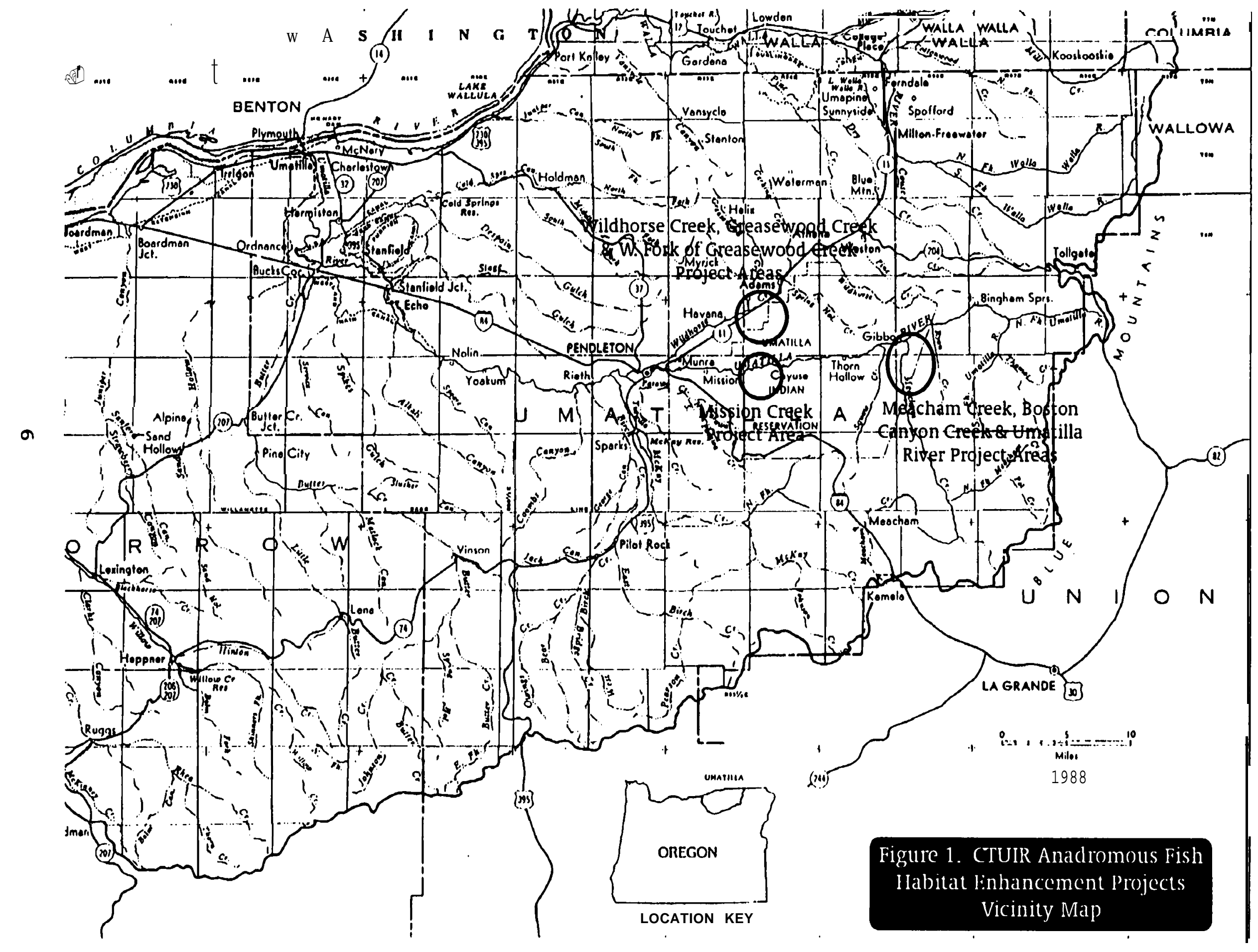




\section{METHODS AND MATERIALS}

\section{Objective I. Maintain and Continue Implementation of Habitat Enhancement Projects throughout the Umatilla River Watershed.}

\section{Pre-construction Preparation:}

\section{a. $\quad$ Assess Maintenance Needs}

The physical condition of all improvements and general stream hydraulics were evaluated in the Meacham Creek, Boston Canyon Creek, Umatilla River and Wildhorse Creek project areas in late May 1995. following spring high flow events, to evaluate effectiveness and prescribe improvements and maintenance to occur in the summer of 1995 as needed.

\section{b. BIA Right-of-Wav Clearances and CIUIR Riparian Easements}

The BIA requires a land survey of designated project area boundaries and the acquisition of a right-of-way agreement on private, Indian-owned Reservation properties (trust lands), prior to pursual of an easement. These agreements require considerable effort and landowner coordination.

Fifteen year riparian easements were pursued and developed for habitat implementation activities on Reservation lands in the Mission Creek Drainage and on non-Indian owned properties on Wildhorse Creek and Greasewood Creek/West Fork Greasewood Creek outside of Reservation Boundaries. An attempt was made to address landowner needs (livestock water gaps, stream crossing sites, etc.) and incorporate these needs into the final project design. Riparian easements protect habitat improvements and insure a fifteen year recovery period within project areas. Easements developed during the 1994 95 work period for Meacham Creek Reservation trust lands were implemented on the ground during the 1995 - 96 work period.

\section{c. Project Cost Share}

Cost share funds were obtained and combined with BPA funds for financial assistance with 1995 habitat implementation activities. These efforts effectively forge partnerships between resource agencies and the public and allow BPA funds to go further.

\section{d. $\quad$ Fill and Removal Permits}

Instream work activities on the Umatilla Indian Reservation require a Tribal Stream Zone Alteration Permit and a U.S. Army Corps of Engineers (COE) 404 Permit. Instream work activities off of the reservation generally require a General Authorization for Fish Habitat Enhancement Permit from the Oregon Division of State Lands (ODSL) in 
conjunction with a Corps 404 Permit. Applications for these permits should be completed and returned to the respective agencies a minimum of 90 days prior to anticipated instream work Permitted instream work activities in the Umatilla River Basin are restricted to instream work periods. These instream work periods are based upon when migrating and spawning salmonids are least likely to be impacted by fill and removal activities. Work windows vary throughout the basin.

\section{e. On-site Cultural/Archeological Monitoring}

All habitat improvement projects utilizing federal monies and involving ground disturbance (high tensile fence construction, instream structures keyed into streambanks. etc.) either on or off the Reservation require a cultural resource clearance, prior to project implementation. CIUIR's Cultural Resource Staff conduct file and literature searches, pedestrian surveys and/or archeological excavations on habitat improvement sites involving ground disturbance activities to determine if cultural resources potentially eligible for inclusion to the National Register of Historic Places are present on the site. Final reports documenting their findings are prepared and submitted to the BIA Umatilla Agency Real Property Management Office (for implementation efforts on the Reservation) and to the State Historic Preservation Office (for implementation efforts, both on and off the Reservation). All cultural clearances are obtained in compliance with Section 106 of the National Historic Preservation Act.

\section{f. Design and Lavout}

Design and layout of new habitat enhancement projects and existing project areas consisted of determining the quantity and type of materials required to build or repair fence and instream structures and develop heavy equipment access sites, haul roads and boulder/gravel storage sites. Proposed fence lines, instream structure sites and streambank areas were staked and flagged to provide assistance to sub-contractors.

\section{g. Contracts}

Proposed implementation activities requiring rental of heavy construction equipment or construction of high tensile smooth wire fencing were advertised and pre-bid tours provided to potential sub-contractors. A notice to proceed was issued in writing to the selected sub-contractor, and a sub-contract was developed to implement the improvements.

\section{h. $\quad$ High Tensile Fence Materials Purchase}

High tensile fence construction materials were purchased for installation of riparian corridor fences. Fence materials were also purchased and stockpiled for implementation activities to occur in the 1996 - 97 project period. 
i. $\quad$ Native Grasses, Riparian Shrubs and Trees

The CTUIR Habitat Enhancement Project practices and promotes the utilization of "native" plant species for ecosystem restoration. Native plants are acclimated to the local climate, provide natural forage for wildlife and are much more resistent to the area's disease and insect problems. Studies have found that exotic species may out-compete and displace native riparian vegetation (Gordon et al., 1993). The planting of exotic species may also introduce foreign organic matter into the ecosystem and change the timing and rate of processing of the material (Campbell et al., 1990).

An effort should always be made to locally acquire indigenous tree and shrub species. Native tree species obtained from other localities may not have the long-term ability to survive and reproduce because the environment may be different from their place of origin. There may also be concerns about pollution of the gene pool of existing plant populations when non-local plants are introduced to a site (Lambert et al.. 1995). The majority of native trees and shrubs planted in the Wildhorse Creek, Greasewood Creek and West Fork Greasewood Creek project areas were cuttings gathered locally by Umatilla Salmon Corps' participants. However, bareroot trees and shrubs could not be readily obtained in the local area. Additional trees and shrubs grown at elevations similar to Wildhorse Creek, Greasewood Creek and West Fork of Greasewood Creek project sites were purchased from nurseries in Eastern Idaho and Washington. Native grass seed and close replicates of native grass seed were also unavailable locally and had to be purchased from Grassland West Seed Company in Clarkston, Washington.

\section{j. $\quad$ Transect and Photo Point Establishment}

Permanent transects were established at channel cross sections in the Wildhorse Creek, Greasewood Creek and West Fork of Greasewood Creek project areas, prior to project implementation to obtain baseline data regarding channel morphology and riparian vegetation. These measurements will be repeated at $3-5$ year intervals.

Permanent photo points were established prior to project implementation in conjunction with the permanent transects. Standardized photos will be taken each autumn to provide a visual record of changes in channel morphology and riparian recovery.

\section{Maintain and Implement Habitat Enhancements:}

\section{a. $\quad \underline{\text { Rock Delivery }}$}

Diced rock was purchased and delivered to the Wildhorse Creek, Greasewood Creek and West Fork of Greasewood Creek project areas for construction of instream sediment retention structures. Structures previously placed between RM 9.5 and RM 10.25 Wildhorse Creek during the 1994 - 95 project period were repaired at that time. 


\section{b. $\quad$ Contractor Supplies and Materials}

CTUIR furnished high tensile smooth wire fence materials to fence sub-contractors for construction of fence on private properties in the Meacham Creek, Wildhorse Creek, Greasewood Creek, West Fork of Greasewood Creek and Mission Creek drainages.

\section{c. $\quad$ Sediment Retention Structures}

Sediment retention structures (check dams) were placed into stream channels and keyed into adjacent streambanks in the Wildhorse Creek, Greasewood Creek and West Fork of Greasewood Creek project areas. The sediment retention structures are designed to assist in speeding riparian recovery by slowing water velocities, recruiting sediments and depositing sediments onto streambanks to provide substrate for revegetation. Sediment structures previously placed into Wildhorse Creek during the 1994 - 1995 project period were also repaired at this time.

\section{d. Instream and Bank Stabilization Maintenance}

CIUIR Habitat Enhancement Project Personnel routinely perform structural maintenance activities in project areas. Structures are periodically hilti-cabled to increase stability and ensure long-term structural integrity. Logs recruited into the stream channels are cabled to boulders and structures to provide instream cover for salmonids and to assist in rebuilding streambanks by slowing water velocities and capturing sediment deposits.

\section{e. $\quad$ Livestock Exclusion and Riparian Corridor Fencing}

High tensile smooth wire fences were constructed to exclude livestock and provide riparian protection and recovery. These fences can be installed in such a manner that multiple pastures can be developed in flood plain areas to reduce grazing intensity and assist the landowner in developing rest/rotation grazing systems.

High tensile corridor fencing, gates and cross section fences in existing Meacham Creek Boston Canyon Creek, Umatilla River and Wildhorse Creek project areas were repaired as needed. Frequent fence inspections were conducted throughout the project period to ensure continued exclusion of livestock and to allow for continued riparian recovery inside of project areas.

\section{f. $\quad$ Construction Activities - Project Review and Inspection}

Prior to commencement of a sub-contract, the sub-contractor meets with CIUIR Habitat Enhancement Project Personnel to discuss sub-contract terms and work performance requirements, work progress schedule, petroleum spill plans and fire prevention and suppression plans. 
The sub-contractor provides and maintains an inspection system acceptable to the CTUIR covering the services under the sub-contract. Complete records of all inspection work performed by the sub-contractor are maintained and made available to the CIUIR during sub-contract performance and for as long afterwards as the sub-contract requires.

Equipment is inspected at the time it is delivered to the worksite. Equipment must be in good working condition, free from excessive leaks in hydraulic, fuel and power systems and clean enough to allow close inspection of these systems. Equipment that does not meet sub-contract specifications and requirements is rejected.

CTUIR Habitat Enhancement Project Personnel monitor the sub-contractors progress and photo document various stages of project implementation.

\section{g- $\quad \underline{\text { Revegetation }}$}

Native riparian tree and shrub species were planted along toe dikes, bank revetment structures, sediment retention structures and pool edges throughout enhancement areas to improve bank stability, provide insect drop, shade the stream channel and provide future recruitable large woody debris. Streambanks. terraces and disturbed sites within the project areas were seeded with native grasses and/or close equivalents of native grasses to improve bank stability and to provide vertical surfaces to capture and retain sediments during high flow events.

3. Post-construction Activities and Habitat Enhancement Monitoring:

a. $\quad$ Post-construction Final Review

CTUIR Habitat Enhancement Project Personnel visit implementation sites immediately following final construction as indicated by the sub-contractor. Sub-contracted services are inspected to determine whether they conform with sub-contact requirements. If the sub-contract services are not accepted, CTUIR may require the sub-contractor to perform the services again in conformity with the sub-contract requirements.

\section{b. Transect Measurements and Photo Point Monitoring}

CIUIR established transects in the Meacham Creek, Umatilla River and Wildhorse Creek project areas, prior to initial implementation efforts. Measurements are repeated at 3-5 year intervals following project implementation to measure changes in channel morphology and vegetative response to habitat enhancements.

Permanent photo points were established prior to project implementation in conjunction with the transects. Standardized photos continue to be taken each autumn to provide a visual record of changes in channel morphology and riparian recovery. A photo point notebook containing $35 \mathrm{~mm}$ slides of annual changes at each photo point is currently 
maintained by the CTUIR Fisheries Habitat Enhancement Project.

\section{c. $\quad$ Physical Condition of Improvements and General Stream Hydraulics}

The physical condition of all improvements and general stream hydraulics were evaluated following spring 1996 high flow events to prescribe improvements and maintenance to occur in the summer of 1996 (1996 - 97 project period).

Objective II. Collect Baseline Water Ouality Data and Continue Post-project Monitoring to Identifv Watershed Health Concerns and to Ouantify the Short and Long- Term Effects of Habitat Enhancement Activities in the Umatilla River Basin.

1. Determine Existing Land Use Practices Impacting Salmon and Steelhead Habitat Capability:

\section{a. $\quad$ Identification of Maior Land Use Practices}

Past and present land use practices (dryland agriculture, irrigated agriculture. grazing, timber harvest, community developments, roads and railroads, etc.) within major subbasins of the Umatilla River Watershed continued to be identified during the project period. A data layer based on this theme is being developed for a GIS data base. Individual land use practices are currently being mapped by area. This effort is being coordinated with the CI'UIR GIS Planning Staff

\section{b. Identification of Site Specific Detrimental Land Use Practices}

Areas where poor land use practices have altered natural floodplain dynamics and significantly reduced or eliminated critical fisheries habitat continued to be identified. These practices include improper tillage methods, overgrazing, overharvest of timber, floodplain encroachment due to development, stream channel constrainment and downcutting from road and railroad building and maintenance activities, etc. Problem areas are being assigned a rating of poor, fair and good and this information is being incorporated into a data layer for a GIS data base. Maps of major subbasins are being developed illustrating where these problem areas occur. Areas throughout the watershed, which are determined to have poor quality habitat, will be targeted for future habitat enhancement projects. This effort is being coordinated with NRCS and the CTUIR GIS Planning Staff.

\section{Fish Habitat Surveys:}

CTUIR Habitat Enhancement Project Personnel conducted physical habitat surveys in the Wildhorse Creek Watershed during the 1995 field season. Data collection methods developed by the ODFW Aquatic Inventory Program will be utilized to sample various habitat parameters. This information should prove useful in identification of habitat 
deficient areas within the watershed in which to focus habitat restoration efforts. The CTUIR UBNPME Staff conducted additional habitat surveys in conjunction with biological inventories in other Umatilla River Watershed subbasin areas. These surveys will assist in determining the relations of anadromous fish habitat and abundance in different types of stream channels from a total basin perspective.

\section{Aquatic Macroinvertebrate Sampling:}

CTUIR Habitat Enhancement Project Personnel identified sampling sites upstream of, downstream of and within enhancement areas to comparatively monitor macroinvertebrate populations and diversity within enhanced areas versus adjacent unenhanced stream reaches.

\section{Water Temperature Monitoring:}

Ryan Tempmentor and Ryan RTM 2000's thermographs were deployed within selected stream reaches (see Figure 2) in the upper Umatilla River Watershed. Several of these instruments were installed upstream, downstream and/or within project areas in Meacham Creek the upper Umatilla River and Wildhorse Creek to monitor the effectiveness of habitat improvements on water temperature cooling. The remaining thermographs were installed in Mission Creek Buckaroo Creek Squaw Creek and at RM 56 Umatilla River to obtain data on potential habitat limiting factors and existing water quality conditions.

All thermographs were deployed in May 1995. The instruments were recovered, downloaded into a computer program and redeployed in November/December 1995. The thermographs collected one temperature reading per hour. Maximum, minimum and average daily water temperatures were compiled in tabular form. Water temperatures were graphed during warmer months (June, July, August and September) to determine if temperatures were reached which could prove detrimental to salmonids. 


\begin{tabular}{|c|c|}
\hline \multicolumn{2}{|r|}{ Location } \\
\hline 1. & Umatilla River - RM 56 @ West Reservation Boundary \\
\hline 2. & Umatilla River - RM 78.5 (downstream mouth of Meacham Creek) \\
\hline 3. & Umatilla River - RM 79 (upstream mouth of Meacham Creek) \\
\hline 4. & $\begin{array}{l}\text { Umatilla River - RM } 81.7 \text { @ USGS Gage Station No. } 14020000 \text { (East } \\
\text { Reservation Boundary) }\end{array}$ \\
\hline 5. & $\begin{array}{l}\text { Wildhorse Creek - RM } 0 \text { upstream from confluence with Umatilla } \\
\text { River }\end{array}$ \\
\hline 6. & $\begin{array}{l}\text { Wildhorse Creek - RM } 9.5 \text { upstream from mouth of Greasewood } \\
\text { Creek }\end{array}$ \\
\hline 7. & Wildhorse Creek - RM 26 \\
\hline 8. & Mission Creek - RM 3.7 downstream of stream forks \\
\hline 9. & Buckaroo Creek - RM 2 \\
\hline 10. & Squaw Creek - RM 2 \\
\hline 11. & Squaw Creek - RM9 @ Little Squaw Creek confluence \\
\hline 12. & Meacham Creek - RM 2 @ USGS Gage Station No. 14020300 \\
\hline 13. & Meacham Creek - RM5.25@ East Reservation Boundary \\
\hline
\end{tabular}

5. Suspended Sediment Monitoring:

Three Isco Model 2700 Wastewater Samplers were deployed to obtain estimates of suspended sediments. These sampling sites included RM 81.7 Umatilla River, RM 56 Umatilla River and RM 2 Meacham Creek Sampling sites were located at or near thermographs and gage stations (see Figure 3 for gage station agency and identification numbers).

Samples were taken year round at 6 hour intervals to create a composite daily sample. The samples were processed monthly by Umatilla National Forest Service Personnel at the U.S. Forest Service (USFS) Lab in Pendleton, Oregon to determine Jackson Turbidity Units, conductivity and total dissolved solids. CIUIR staffcorrelated suspended sediment data with stream flow data collected from the adjacent gage stations to arrive at daily sediment loads (tons/day) estimates. 


\begin{tabular}{||l||}
\hline \hline Figure 3. $\quad$ Suspended Sediment Monitoring Sites 1995 \\
\hline \multicolumn{1}{||c||}{ Location } \\
\hline Umatilla River - RM 56 @ West Reservation Boundary \\
\hline $\begin{array}{l}\text { Umatilla River - RM } 81.7 \text { @ USGS Gage Station No. 14020000 (East Reservation } \\
\text { Boundary) }\end{array}$ \\
\hline Meacham Creek - RM 2 @ USGS Gage Station No. 14020300 \\
\hline \hline
\end{tabular}

Objective III: Continue Watershed Planning/Scoping/Education Process by Identifying Problems and Developing Creative Solutions to Land Use Problems Impacting Fisheries Habitat in the Umatilla River Basin:

\section{Community Outreach Effort:}

An extensive outreach effort at the local community level continued to be conducted throughout the 1995 - 96 project period to identify interested individuals, special interest groups and agencies and encourage their involvement for scoping of issues, identification of opportunities and development of mitigation efforts. This educational effort involved distribution of habitat/watershed literature, attending public and agency meetings to promote watershed restoration efforts and providing presentations to the public and special interest groups. Such activities serve to increase public awareness of habitat and watershed health issues in the Umatilla River Basin and foster landowner cooperation regarding habitat restoration efforts.

\section{Scoping Groups:}

The CIUIR Habitat Enhancement Project met with a scoping group comprised of local landowners and resource agencies in the Mission Creek Watershed to familiarize landowners with restoration/management practices and to receive their input regarding potential implementation of such improvements in the Mission Creek Watershed. Scoping group input will be documented.

\section{Public Educational Opportunities:}

The CTUIR Habitat Enhancement Project participated in workshops, provided riparian improvement training opportunities and provided tours of habitat enhancement project areas to interested public, resource agency personnel, and Umatilla Salmon Corps Members throughout the 1995 - 96 project period. 


\section{Public Monitoring Programs:}

The CIUIR Habitat Enhancement Project coordinated with other resource agencies and environmental groups to promote citizen involvement and commitment to watershed health by encouraging the development of community stream monitoring programs.

\section{Educational Brochure:}

CIUIR Habitat Enhancement Project Personnel temporarily suspended development of an educational brochure highlighting successful riparian enhancements. Funds were utilized to produce visual displays of land use impacts and watershed restoration/habitat enhancement measures for use at workshops and public meetings.

\section{Objective IV. Pursue Alternative Management Methods to Mitigate Impacts from Past and Ongoing Land Management Activities:}

\section{Acquisition Land/Management Rights:}

An attempt was made to identify properties available for purchase, containing significant reaches of high quality or potentially high quality anadromous salmonid habitat in the Umatilla River Basin, and explore funding opportunities for land acquisition. Properties purchased will be restored as needed and/or protective management measures implemented.

Management rights, including water rights, timber rights and grazing rights, can also be acquired to provide fisheries habitat protection. Purchase of management rights would restrict landowners from various land use activities over a period of time. The term of an agreement is dependent upon the current habitat condition of the site being protected and the desired future condition. 


\section{RESULTS AND DISCUSSION}

Objective I. Maintain and Continue Implementation of Habitat Enhancement Projects throughout the Umatilla River Watershed.

1. Pre-construction Preparation:

a. $\quad$ Assess Maintenance Needs

The physical condition and structural integrity of improvements within Meacham Creek, Boston Canyon Creek, Umatilla River and Wildhorse Creek project areas was evaluated following spring 1995 high flow events. It was determined that a heavy equipment rental sub-contract would need to be developed for repair of 18 sediment retention structures, previously placed between RM 9.5 and RM 10.25 Wildhorse Creek during the 1994 - 95 project period. Minor high tensile smooth wire fence maintenance in project areas was accomplished by CTUIR Habitat Enhancement Project Personnel.

\section{b. $\quad$ BIA Right-of-Wav Clearances and CIUIR Riparian Easements}

BIA clearances were not required during the 1995-96 project period because no agreements were secured on Indian allotments. However, CIUIR Habitat Enhancement Project Personnel did begin negotiation of agreements with several Indian allotment owners in the Buckaroo Creek Watershed. Initial habitat enhancement efforts in the Buckaroo Creek Drainage have been proposed in the 1996 - 97 Umatilla River Basin Anadromous Fish Habitat Statement of Work

A 15 year riparian easement was entered into on January 1, 1996 for an Indian-owned property located within Reservation Boundaries. This property, owned by Mr. Steven Filkins, is comprised of two Umatilla County tax lots between RM 2.9 and RM 3.3 Mission Creek Habitat enhancement efforts implemented on this property represent CIUIR's initial restoration efforts in the Mission Creek Watershed.

CTUIR secured two riparian easements on Wildhorse Creek during the project period. CFUIR entered into a fifteen year riparian easement with Mrs. Lois Hartley and Mrs. Helen Morrison on October 12. 1995 for improvement of the riparian corridor between RM 11.5 and RM 11.75 Wildhorse Creek A fifteen year riparian easement was also entered into on October 12,1995 between CIUIR, Mr. John P. Adams and John W. Adams for improvement of the stream corridor area between RM 11.75 and RM 12.5 Wildhorse Creek.

Two riparian easements were secured for properties located between RM 0 and RM 1.5 Greasewood Creek and RM 0 and RM 0.25 West Fork Greasewood Creek These properties are owned by the following individuals: 1) Mr. Melvin Schmidtgall and Mr. Robert Miller (S\&M Farming Company), Mrs. Terry Schmidtgall. Mrs. Janet Miller, Mrs. Lynn WaIker and 
Ms. Virginia Whitacre, and 2) Mrs. Beverly Rothrock and Mr. Kent Rothrock (this property has since been sold to Mr. Calvin Spratling). Both agreements are effective for a fifteen year period from October 12,1995 through October 12.2010. These easements represent CTUIR's initial habitat improvement efforts in the Greasewood Creek Drainage.

\section{c. Project Cost Share}

A \$10,000 USFWS Partners for Wildlife Habitat Restoration Grant was awarded to CI'UIR on August 26, 1994 during the 1994 - 95 project period. These funds were utilized by CTUIR for construction of 8,005 feet of high tensile smooth wire fence between RM 11.5 and RM 12.5 Wildhorse Creek and installation of 3,685 feet of smooth wire between RM 10.25 and RM 10.5 Wildhorse Creek during the 1995 - 96 project period. BPA monies purchased native plant materials and grass seed in these project areas.

The CTUIR Habitat Enhancement Project coordinated with CIUIR Environmental Protection/Rights Protection Staff to acquire EPA 319 Non-point Source Pollution Grant Monies to address water quality/habitat problems in the Mission Creek Watershed. These funds were utilized to subcontract 4,079 feet of high tensile smooth wire fence construction between RM 2.9 and RM 3.3 Mission Creek BPA funds covered the personnel services necessary to accomplish this project.

BIA funds were used to purchase fence materials for construction of high tensile smooth wire fencing between RM 11.5 and RM 12.5 Wildhorse Creek and RM 2.9 and RM 3.3 Mission Creek BIA funds were cost shared with BPA funds to subcontract the construction of 4.500 feet of high tensile smooth wire fencing between RM 4.25 and RM 4.75 Meacham Creek BIA funds paid for all noxious weed control subcontracts developed during the project period.

\section{d. $\quad$ Fill and Removal Permits}

CTUIR Habitat Enhancement Project Personnel completed and submitted instream fill/removal permit applications to COE and ODSL in early June 1995 for placement of gravel sediment retention structures between RM 11.5 to RM 12.5 Wildhorse Creek, RM 0 to RM 1.5 Greasewood Creek and RM 0 to RM 0.25 West Fork of Greasewood Creek during the 1995 instream work window. CIUIR received a General Authorization for Fish Habitat Enhancement from ODSL on June 19.1995 and 404 Permits from COE on August 15. 1995 authorizing these instream activities.

\section{e. $\quad$ On-site CuItural/Archaeological Monitoring}

The CIUIR CuIturaI Resource Staff conducted pedestrian surveys in proposed habitat enhancement project areas to determine if cultural resources potentially eligible for inclusion to the National Register of Historic Places were present on the sites. These surveys were required prior to project implementation. Pedestrian surveys conducted in 
the lower Greasewood Creek Drainage and in the lower Mission Creek Watershed resulted in the discovery of pre-historic and historic cultural materials. The CTUIR Cultural Resources Staff determined that installation of riparian corridor fencing would have no adverse impacts on cultural resources in these areas and would protect other potential historic cultural materials on properties within proposed fence boundaries from further disturbances.

Final reports documenting these findings were prepared and submitted to the BIA Umatilla Agency Real Property Management Office (for Mission Creek properties on the Reservation) and to the State Historic Preservation Office (for Mission Creek, Greasewood Creek and West Fork of Greasewood Creek properties).

\section{f. Design and Lavout}

Proposed riparian corridor fence lines and fence structure locations were staked between RM 11.5 and RM 12.5 Wildhorse Creek, RM 0 and RM 1.5 Greasewood Creek, RM 0 and RM 0.25 West Fork of Greasewood Creek and RM 2.9 and RM 3.3 Mission Creek to assist fence subcontractors. Instream structure locations were staked within proposed Greasewood Creek, West Fork of Greasewood Creek and Wildhorse Creek project areas and at existing structure sites in the 1994 Wildhorse Creek Project Area (RM 9.5 to RM 10.5) to provide site assistance to the heavy equipment operator. Diced rock was delivered to the project sites for construction and repair of sediment retention structures.

\section{g. $\quad$ Contracts}

A 19 day heavy equipment rental sub-contract was issued to K.R. Strickland Company Building and Excavation on September 13, 1995 for placement and repair of instream sediment retention structures in the Greasewood Creek and Wildhorse Creek project areas.

A fence sub-contract for installation of 4.500 feet of high tensile smooth wire fencing between RM 4.25 and RM 4.75 Meacham Creek was issued to Borgerding Construction on July 19, 1995.

A sub-contract was awarded to Young's Contracting on January 25,1996 for construction of 18,375 feet of high tensile smooth wire fence between RM 0 and RM 1.5 Greasewood Creek and RM 0 and RM 0.25 West Fork of Greasewood Creek

Additional fence sub-contracts were funded with EPA and USFWS funds. All contracted services were completed in a satisfactory manner. 


\section{h. $\quad$ High Tensile Fence Materials Purchase}

Pressure treated, pointed and capped fence posts, tamarack fence stays, high tensile smooth wire and miscellaneous fence hardware was purchased to construct riparian fencing in the Meacham Creek, Mission Creek, Wildhorse Creek and Greasewood Creek drainages during the project period and in the 1996 - 97 project period.

BIA and USFWS funds were used to purchase 15,769 feet of high tensile smooth wire fence materials constructed in the Mission Creek and Wildhorse Creek project areas. BPA monies purchased 22,875 feet of fence materials constructed in the Meacham Creek and Greasewood Creek drainages. Remaining fence materials will be used during the 1996 97 project period.

i. $\quad$ Native Grasses. Riparian Shrubs and Trees

Approximately 5,000 native trees and shrubs were purchased or gathered for planting in the Wildhorse Creek, Greasewood Creek and West Fork of Greasewood Creek project areas. Bareroot trees purchased included the following: 700 black cottonwoods, 400 redosier dogwoods, 400 serviceberries, 400 chokecherries and 200 ponderosa pines. All bareroot trees and shrubs were purchased from Plants of the Wild in Tekoa, Washington, Clifty View Nursery in Banners Ferry, Idaho, and the Umatilla National Forest in Pendleton, Oregon. An additional 2,700 to 2,900 black cottonwood, redosier dogwood, chokecherry, snowberry and willow (three native species) cuttings were gathered locally by Umatilla Salmon Corps Participants.

Grass seed was purchased from Pendleton Grain Growers in Pendleton, Oregon and Grassland West Seed Company in Clarkston, Washington- Five hundred pounds of annual rye grass was purchased to seed streambank areas disturbed by heavy equipment in the Wildhorse Creek, Greasewood Creek and West Fork of Greasewood Creek project areas. Six hundred and seventy-six pounds of native grass seed and native grass seed equivalents were purchased to seed riparian corridor areas in the Wildhorse Creek, Greasewood Creek and West Fork of Greasewood Creek project areas. This seed mix contained $40 \%$ western wheatgrass, $25 \%$ sand dropseed, $18 \%$ great basin wild rye and $17 \%$ Sherman big bluegrass. Four hundred and seventy-nine pounds of native grass seed and native grass seed equivalents were purchased to seed terraces and dry sites in the Wildhorse Creek, Greasewood Creek and West Fork of Greasewood Creek project areas. This seed mix included 36\% Indian ricegrass, 36\% western wheatgrass, $12 \%$ great basin wild rye, $9 \%$ sand dropseed and $6 \%$ Sherman big bluegrass. Twenty-five pounds of tufted hairgrass was purchased to seed sediment retention structures and channel margins in the Wildhorse Creek, Greasewood Creek and West Fork of Greasewood Creek project areas. 
j. $\quad$ Transect and Photo Point Establishment

Prior to project implementation, transects were established at 11 channel cross section sites between RM 11.5 and RM 12.5 Wildhorse Creek and at 7 channel cross section sites between RM 0 and RM 1.5 Greasewood Creek and RM 0 and RM 0.25 West Fork of Greasewood Creek to obtain baseline data regarding channel morphology and riparian vegetation. These measurements will be repeated at three to five year intervals, thereafter.

Permanent photo points were established in conjunction with the transects. Slides were taken at the transect sites to document pi-e-project conditions. Slides will continue to be taken each autumn to provide a visual record of changes in channel morphology and riparian recovery.

2. Maintain and Implement Habitat Enhancements:

a. $\quad$ Rock Delivery

Birch Creek Construction, Inc. in late August and early September 1995 delivered 1300 cubic yards of diced rock varying from 2 to 20 inches in diameter to the Wildhorse Creek, Greasewood Creek and West Fork of Greasewood Creek project areas for construction and repair of instream sediment retention structures.

\section{b. $\quad$ Contractor Supplies and Materials}

A total of 38,644 feet of high tensile smooth wire fence materials was supplied to fence sub-contractors during the project period. BPA funds were used to supply 22,875 feet of these materials, while an additional 15,769 feet of fence materials were purchased with BIA and USFWS funds.

\section{c. $\quad$ Sediment Retention Structures}

Eighteen sediment retention structures (check dams) were repaired between RM 9.5 and RM 10.25 Wildhorse Creek These structures functioned adequately under normal stream flow conditions, depositing several tons of sediments on streambanks throughout the winter of 1994 - 1995. However, due to poor quality rock being used at the time of construction, several structures failed to withstand winter 1995 high flow events. Larger, more durable rock was utilized during the project period to improve the integrity of the structures. Better quality rock was also utilized to place additional sediment retention structures in new project areas. An additional 6 structures were placed between RM 10.25 and RM 10.5 Wildhorse Creek 7 structures between RM 11.5 and RM 12.5 Wildhorse Creek, and 32 structures between RM 0 and RM 1.5 Greasewood Creek and RM 0 and RM 0.25 West Fork of Greasewood Creek 
The structures were designed by Ed Calame, Hydrological Technician, with the Umatilla National Forest. Each structure consists of approximately 18 to 20 cubic yards of diced rock varying from 2 to 20 inches in diameter. The structures were placed throughout the length of the project areas, so that there is one structure per each one foot rise in stream bed gradient from the upper to lower pool to create a back water and allow for sufficient fish passage. The structures have an 8:2 slope of repose and are keyed into adjacent streambanks. The structures are approximately 12 feet in length.

The sediment structures were effective in capturing sediment loads and depositing sediments onto streambanks during 1995 - 96 high flow events. Sediment bars, which formed on streambanks upstream of the structures, were seeded with native grasses and planted with trees and shrubs.

\section{d. Instream and Bank Stabilization Maintenance}

CTUIR Habitat Enhancement Project Personnel hilti-cabled existing bank and instream structures, following spring 1995 high flow events, in the Meacham Creek, Boston Canyon Creek and Umatilla River project areas to increase stability and long-term structural integrity. Logs recruited into the stream channels during high flow periods were cabled to boulders and structures to provide instream cover for salmon and steelhead and to assist in rebuilding streambanks by slowing water velocities and capturing sediments for substrate.

\section{e. Livestock Exclusion and Riparian Corridor Fencing}

BPA funds were cost shared with BIA funds to install high tensile smooth wire fence between RM 4.25 and RM 4.75 Meacham Creek to exclude cattle from floodplain areas, the riparian corridor and spring sites. BPA funding also covered high tensile smooth wire fence construction costs between RM 0 and RM 1.5 Greasewood Creek and RM 0 and RM 0.25 West Fork Greasewood Creek Four livestock water gaps/equipment crossings were incorporated into the Greasewood Creek/West Fork Greasewood Creek project area fence design. Three multiple pastures were created in adjacent floodplain areas (without requiring the use of additional fence materials) outside of the riparian exclosure fencing to assist the landowners in development of rest-rotation grazing strategies. USFWS and EPA monies funded additional fence sub-contracts on Mission Creek and Wildhorse Creek

Minor fence repair was performed by CTUIR Habitat Enhancement Project Personnel in the Meacham Creek, Boston Canyon Creek, Umatilla River and Wildhorse Creek project areas.

\section{f. $\quad$ Construction Activities - Project Review and Inspection}

CTUIR Habitat Enhancement Project Personnel met with the equipment rental contractor and fence contractors, prior to proposed project implementations to discuss sub-contract 
terms and work performance requirements, work progress schedules, petroleum spill plans and fire prevention and suppression plans.

Equipment was inspected at the project sites by CIUIR Habitat Enhancement Project Personnel and determined to be in good working order, free from excessive leaks in hydraulic, fuel and power systems. Contractors maintained a daily log and work progress schedule.

CIUIR Habitat Enhancement Project Personnel photo documented various stages of project implementations.

$$
\text { g- } \quad \underline{\text { Revegetation }}
$$

Umatilla Salmon Corps Participants assisted the CTUIR Habitat Enhancement Project in planting approximately 5,000 native trees and shrubs throughout the Wildhorse Creek, Greasewood Creek and West Fork of Greasewood Creek project areas. Trees and shrubs were planted in November, December, March and April of the project period.

No intensive tree planting efforts were undertaken in the Meacham Creek/Boston Canyon Creek project areas due to high natural recovery rates of alder and willow species in riparian corridors.

Streambanks in the Wildhorse Creek, Greasewood Creek and West Fork of Greasewood Creek project areas, disturbed from heavy equipment, were seeded with annual rye immediately following placement of sediment retention structures to slow potential erosion during the winter months. These areas also were seeded with native grass mixes or close equivalents in April 1995 to assist in stream channel stability and filtering of sediments during high flow periods. Sediment retention structures in these project areas will be seeded with tufted hair grass during the summer of 1996 to assist in stabilization of these structures.

3. Post-construction Activities and Habitat Enhancement Monitoring:

\section{a. $\quad$ Post-construction Final Review}

CIUIR Habitat Enhancement Project Personnel inspected final construction of sediment retention structures in the Wildhorse Creek, Greasewood Creek and West Fork of Greasewood Creek project areas and high tensile smooth wire fence in the Meacham Creek. Greasewood Creek and West Fork of Greasewood Creek project areas and determined that services performed were consistent with sub-contract requirements. 


\section{b. $\quad$ Transect Measurements and Photo Point Monitoring}

Stream channel cross sections were not scheduled to be measured at established transect sites in the Meacham Creek, Boston Canyon Creek and Umatilla River project areas. These cross sections will continue to measured at three to five year intervals.

Slides continued to be taken at all 60 photo point locations within the Boston Canyon Creek, Meacham Creek, Umatilla River and Wildhorse Creek project areas to document project recovery and to provide a visual record of annual changes within the floodplain. Photographs indicate an upward, downward, or static trend in woody vegetation, streambank stability and cover (Meyers, 1987). However, initial vegetation "expression", obvious in photographs, should not be confused with vegetation "succession" required for stream ecosystem health (Ehnore and Beschta, 1987).

\section{c. Physical Condition of Improvements and General Stream Hydraulics}

The physical condition and structural integrity of improvements within project areas was evaluated following spring 1996 high flow events. It was determined that some repair and maintenance of sediment retention structures in the Wildhorse Creek, Greasewood Creek and West Fork of Greasewood Creek project areas would be required in the 1996 97 project period. Major flood events in late November 1995 and early February 1996 damaged approximately 1.75 river miles of high tensile smooth wire riparian fencing in the Meacham Geek and Umatilla River project areas. CTUIR Habitat Enhancement Project Personnel coordinated with Flood Emergency Management Agency (FEMA) Personnel regarding funds for fence repair in these areas. FEMA has indicated that they will reimburse CTUIR for $70 \%$ of flood repair damages. BPA funds will be cost shared with FEMA funds during the 1996 - 97 project period for repairs to flood-damaged fencing.

Objective II. Collect Baseline Water 0uality Data and Continue Post-project Monitoring to Identify Watershed Health Concerns and to Ouantify the Short and Long- Term Effects of Habitat Enhancement Activities in the Umatilla River Basin.

1. Determine Existing Land Use Practices Impacting Salmon and Steelhead Habitat Capability:

a. Identification of Maior Land Use Practices

CTUIR Habitat Enhancement Project Personnel continued to gather historical and current land use data regarding the Mission Creek Subbasin and developed a data layer based on current land use practices for a GIS data base. 


\section{b. Identification of Site Specific Detrimental Land Use Practices}

CIUIR Habitat Enhancement Project Personnel continued to coordinate with the CTUIR Water Resources Program and NRCS to identify land use practices impacting fisheries habitat in the Mission Creek Subbasin. Identified poor land use practices are currently being incorporated into a GIS data layer for a GIS data base.

2. Fish Habitat Surveys:

CTUIR Habitat Enhancement Project Personnel conducted habitat surveys on the lower 13 river miles of Wildhorse Creek (from the mouth to the town of Adams) and within the Greasewood Creek/West Fork Greasewood Creek Project Area. CIUIR Habitat Enhancement Project Personnel anticipate completing a habitat inventory of remaining upper mainstem Wildhorse Creek during the 1995 - 96 project period. Additional surveys were coordinated with and conducted by the CIUIR UBNPME Project on 22.6 stream miles in the Umatilla River Basin. Streams surveyed included RM 81.7 to RM 89.6 Umatilla River, RM 0 to RM 4.4 Moonshine Creek, RM 0 to RM 4.15 Mission Creek, RM 0 to RM 4.1 Cottonwood Creek and RM 0 to RM 2 Cottonwood Creek The UBNPME Project conducted biological inventories in conjunction with the physical surveys. Physical habitat and biological inventory summaries compiled from the 1995 field season have been published in the 1994 - 95 Umatilla Basin Natural Production Monitoring and Evaluation Annual Progress Report. Habitat survey data will be used to determine habitat deficient areas throughout the watershed in which to focus habitat restoration efforts.

3. Aquatic Macroinvertebrate Sampling:

Macroinvertebrate surveys are an important tool in describing the condition and relative health of the aquatic ecosystem. Macroinvertebrates are components of the aquatic environment that provide a connecting link in the food chain between multicelled periphyton. detritus from terrestrial sources and the fish population. As a food source they are essential to the growth and production of fish and, because of their strict habitat requirements, are very useful as indicators of changes in aquatic habitat (USDA, Forest Service. 1985).

The CIUIR Habitat Enhancement Project identified sampling sites upstream of, downstream of and within CTUIR Habitat Enhancement Project Areas to sample macroinvertebrate populations during the 1994 - 95 project period. Sampling equipment was purchased during the 1995 - 96 project period. CIUIR Habitat Enhancement Project Personnel had planned to initiate macroinvertebrate sampling efforts in the fall of 1995 . prior to high flows, and again in the spring of 1996. immediately following high flow events. However, initial sampling efforts will begin in mid summer 1996 due to sampling equipment purchase delays. Samples will be sent to the Bureau of Land Management (BLM) Aquatic Ecosystem Lab in Logan, Utah for processing. Information obtained from the samples should prove useful in providing comparisons between enhanced stream habitat and adjacent unenhanced stream reaches. 


\section{Water Temperature Monitoring:}

Temperatures in excess of $65 \mathrm{~F}$ impair growth and survival in sahnonids (USFWS and National Marine Fisheries Service, 1981). Abnormally high temperature conditions during migration can contribute to outbreaks of disease among adult chinook salmon often resulting in prespawning mortality. Temperatures in excess of $68 \mathrm{~F}$ have been shown to result in impairment of chinook salmon. High stream temperatures may also stress juvenile steelhead during warm summer months. Temperatures exceeding $73 \mathrm{~F}$ result in direct mortality to chinook salmon and steelhead (Bell, 1984).

Thermographs were deployed at thirteen locations, including four sites on the Umatilla River, three sites on Wildhorse Creek, one site on Mission Creek, one site on Buckaroo Greek, two sites on Squaw Greek and two sites on Meacham Greek (see Figure 2, page 14 for river mile locations). Stream temperature data was summarized into tabular form, illustrating maximum, minimum and average daily Celsius and fahrenheit temperatures during thermograph deployment periods. A binder containing annual water temperature tables is maintained in the CTUIR Habitat Enhancement Project Office. Water temperatures have been graphed during warm season months (June, July, August and September) to determine whether temperatures were detrimental to anadromous salmonids. Graphed data can be viewed in Appendix A.

Temperature data was not obtained during the months of May through December 1995 at RM 56 Umatilla River due to the instrument being deployed incorrectly at the field site. Two thermographs were discovered out of water on several occasions during 1995 summer months. This resulted in air temperatures being recorded and water temperature data being lost at RM 78.5 Umatilla River between June 1 through 13 and August 18 through 23 and at RM 9 Squaw Greek between July 15 through August 20. Temperature data for remaining summer days at these locations was graphed (Appendix A, pages 1 and 12). A thermograph was lost at RM 79 Umatilla River during a major flood event in late November 1995 resulting in a loss of all but early summer temperature data. June 1 through 20 data was graphed for this site (Appendix A, page 2). Three thermographs were damaged during an extreme flood event in the first week of February 1996 and had to be sent to Ryan Instruments for repair. It was decided that data will no longer be collected during winter months due to potential damage or loss of thermographs. Future thermograph deployments will continue from May through October, during critical warm season months.

Stream temperatures at RM 78.5 Umatilla River and RM 81.7 Umatilla River frequently exceeded $70 \mathrm{~F}$ from mid July through early August 1995 for two to four hour periods. During these warm months, temperatures in these stream reaches often exceeded $65 \mathrm{~F}$ for 10 to 12 hour periods. Temperatures at RM 78.5 Umatilla River tended to average 1.5 to $2 \mathrm{~F}$ warmer than RM 81.7 Umatilla River temperatures. Meacham Greek discharges into the Umatilla River just upstream of RM 78.5. Apparently Meacham Greek stream flows have a warming effect on this reach of the Umatilla River. 
The maximum summer stream temperature at RM 26 Wildhorse Creek was $72.7 \mathrm{~F}$ on August 4, 1995. Maximum temperatures reached or exceeded $70 \mathrm{~F}$ on 17 days between June 24 and August 6, 1995. Average temperatures exceeded $65 \mathrm{~F}$ on 3 days during this time period. Temperatures recorded at this site during the summer of 1994 did not exceed $70 \mathrm{~F}$ and appeared to average 3 to $4 \mathrm{~F}$ cooler than 1995 summer temperatures. However, June 1995 temperatures were more consistent than June 1994 temperatures and exhibited much less temperature fluctuation. It is not clearly understood why temperatures at this location continue to vary considerably from year to year.

Stream temperatures obtained at RM 0 Wildhorse Creek and at RM 9.5 in the lower Wildhorse Creek Project Area were unusually warm in late May through mid June 1995. The maximum stream temperature at RM 0 on May 31.1995 was $77.9 \mathrm{~F}$ and $76.3 \mathrm{~F}$ at RM 9.5 on the same date. Maximum temperatures at both locations exceeded $80 \mathrm{~F}$ several times in late June 1995. throughout much of July and into early August and reached as high as $82.9 \mathrm{~F}$ at RM 0 on July 19. 1995. Average stream temperatures exceeded $75 \mathrm{~F}$ on July 19 - 22. 1995 at RM 0 and on July 20, 1995 at RM 9.5. Temperatures at RM 0 Wildhorse Creek and RM 9.5 Wildhorse Creek were often similar during periods of rainfall. but varied as much as $4 \mathrm{~F}$ on other summer days with the warmer temperatures being recorded at RM 0 near the mouth of Wildhorse Creek As summer stream flows diminished, temperature differences at the two locations were generally less than $1 \mathrm{~F}$. Daily stream temperatures at RM 0 Wildhorse Creek ranged between 8 to $14 \mathrm{~F}$ warmer than those recorded at RM 26 Wildhorse Creek. Unlike upper Wildhorse Creek, lower Wildhorse Creek (downstream of RM 9.3) maintains perennial stream flows, primarily due to year-round flows provided by the Greasewood Creek System. Therefore, lack of thermal cover (riparian vegetation) throughout much of the length of Wildhorse Creek is suspect of contributing to this downstream warming trend.

Stream temperatures recorded at RM 3.7 Mission Creek during the project period reached a maximum summer temperature of $58.8 \mathrm{~F}$ on September 3, 1995. Average summer temperatures at this site ranged from a low of $48.5 \mathrm{~F}$ on June 6, 1995 to a high of 56.2 F on September 3. 1995. Average temperatures generally remained in the lower 50's F throughout the summer months. While Mission Creek temperatures at this particular site appear to be excellent for salmonid survival and rearing, a habitat inventory conducted during the summer of 1995 documented that $77 \%$ of the stream is dry by mid to late summer. The thermograph at RM 3.7 is currently deployed in one of the more pristine areas in the watershed. Two additional thermographs will be deployed in Mission Creek in the 1996 - 1997 project period to document temperature conditions downstream of this site.

RM 2 Buckaroo Creek stream temperatures were cooler during the summer of 1995 than those recorded during the previous summer. Stream temperatures reached or exceeded $75 \mathrm{~F}$ on 23 different days between July 1, 1995 and August 6.1995. Temperatures in this stream reach frequently exceeded $70 \mathrm{~F}$ for nine to ten hour daily time intervals from late June into early September 1995. 
Stream temperatures recorded at RM 2 Squaw Creek exceeded $70 \mathrm{~F}$ on 23 different days between June 30,1995 and August 6, 1995 for one to four hour intervals. Water temperatures recorded at RM 9 Squaw Creek near the confluence with Little Squaw Creek frequently exceeded $75 \mathrm{~F}$ from late June into early September 1995.

Maximum stream temperatures were similar between RM 2 Meacham Creek and RM 5.25 Meacham Creek with slightly cooler temperatures at RM 2 Meacham Creek This difference may be attributed to vegetative riparian recovery and reduced solar input within the habitat enhancement project area between RM 2 and RM 4.75 Meacham Creek Stream temperatures at both, RM 2 and RM 5.25 exceeded $75 \mathrm{~F}$ on several days from late July into early August 1995.

In general, stream temperatures were 2 to $4 \mathrm{~F}$ cooler in the summer of 1995 than during the previous summer with the exception of RM 26 Wildhorse Creek The majority of streams reaches monitored did not begin to "warm up" (70 F or warmer) until late June or early July and began recording cooler temperatures by mid August 1995. Although RM 0 and RM 9.5 Wildhorse Creek did exhibit a temperature increase for several days in late May and early June 1995. most likely associated with warmer air temperatures and increased solar input. Rainfall late in the third week of June 1995 increased stream flows and significantly reduced stream temperatures for several days at all thermograph deployment sites.

\section{Suspended Sediment Monitoring:}

Siltation, a leading cause of non-point source pollution, is especially harmful to fish and aquatic ecosystems. Sediments harm fish by reducing dissolved oxygen levels and by smothering eggs and newly hatched fry. Sediment deposits also can eliminate aquatic plants that provide cover for fish and the invertebrates they consume (Trout Unlimited, 1994).

CTUIR Habitat Enhancement Project Personnel collected daily suspended sediment data from three ISCO Model 2700 Wastewater Samplers. Data obtained was averaged and combined with gage station stream flow data to arrive at daily estimates of total sediment yield at RM 2 Meacham Creek, RM 56 Umatilla River and RM 81.7 Umatilla River for the 1995 annual year. This information is presented in graphical form in Appendix B. Tabular daily sediment yield data is maintained at the CTUIR Habitat Enhancement Project Office.

Stream flows during 1995 ranged from a peak of $3.450 \mathrm{cfs}$ on November 28, 1995 to a minimum of $8.1 \mathrm{cfs}$ on August 28.1995 at RM 2 Meacham Creek, a peak of 6,160 cfs on November 28, 1995 to a minimum of $42 \mathrm{cfs}$ on September 3, 4 and 5. 1995 at RM 56 Umatilla River, and a peak of 2,300 cfs on February 2, 1995 to a minimum of $38 \mathrm{cfs}$ on September 21 and 22, 1995 at RM 81.7 Umatilla River. The peaks in sediment yield correspond closely to high flow events in winter and early spring. Maximum recorded 1995 daily sediment yields of 3.133 tons per day at RM 2 Meacham Creek on February 
2, 1995, 9,006 tons per day at RM 56 Umatilla River on February 1.1995 and 1188 tons per day at RM 81.7 Umatilla River on February 2, 1995 occurred during major high flow events. Sediment yields were much higher during the 1995 annual year than in previous years. This can be attributed to higher precipitation levels and numerous, erosive flood events throughout the year.

Sediment data was not collected in early January. mid February, late March, early April, late October, the month of November and the month of December due to periodic malfunction of the sediment samplers from flood events. Daily sediment yields unavailable for mid February, late March and late October were obtained by averaging sediment data obtained prior to and following the period of malfunction. These sediment yields were incorporated into corrected monthly sediment load calculations.

Some discrepancy exists in sediment yield data obtained at RM 56 Umatilla River because the sediment sampling station located at RM 56 is upstream from the Wildhorse Creek confluence, and flow data was obtained from Oregon Water Resources Department Gage Station No. 14021000 at RM 53.5 Umatilla River, downstream from the mouth of Wildhorse Creek The CIUIR Water Resources Department in cooperation with U.S. Geological Survey has recently installed a gage station at RM 56. This should help to overcome this problem in the future.

\section{Objective III. Continue Watershed Planning/Scoping/Education Process by Identifving Problems and Developing Creative Solutions to Land Use Problems Impacting Fisheries Habitat in the Umatilla River Basin:}

\section{Community Outreach Effort:}

CTUIR Habitat Enhancement Project Personnel participated in the following outreach efforts during the project period:

Provided tours of BPA funded habitat enhancement areas on Meacham Creek and/or Wildhorse Creek to: 1) Umatilla Basin Watershed Council, 2) Umatilla County Weed and Crop Tour Participants, 3) Representative Chuck Norris, Oregon House District 57. 4) Jerry Bauer and Bob Austin (BPA) to demonstrate program successes.

Coordinated with ODFW and Union Pacific Railroad (UPRR) to establish a trust fund to mitigate for UPRR's potential environmental impacts from proposed double track expansion activities and historical impacts to fisheries resources and fish habitat in the Meacham Creek Drainage. 
Coordinated Mission Creek Watershed restoration efforts with NRCS to: 1) continue development of Mission Creek Watershed Preliminary Report \& Plan of Work, 2) identify baseline monitoring protocol to assess current conditions in the watershed and 3) develop public relations/landowner participation outreach opportunities.

Provided slide presentations/visual displays of detrimental land use practices impacting fisheries habitat in the Umatilla River Basin and CTUIR habitat enhancement efforts to: 1) Ukiah Junior and Senior High School Students, 2) Umatilla County Soil \& Water Conservation District's (SWCD) Nuts and Bolts Watershed Management Workshop Participants, 3) Native American Fish \& Wildlife Society Watershed Workshop Participants, 4) CTUIR Head Start Students and 5) Pendleton High School Science and Math Investigative Learning Experience Students.

Attended Umatilla River Basin Watershed Council and Umatilla County SWCD meetings to update council members on CIUIR habitat enhancement efforts and to provide input on other watershed health issues.

Participated and provided a display and literature at the Columbia River InterTribal Fish Commission's Columbia Basin Watershed Alliances Workshop.

Participated in a meeting with state and county highway departments and natural resource agencies to identify cropland areas in the Wildhorse Creek Watershed impacting roads and waterways and to discuss potential solutions to ending cultivation practices in public owned right-of-way areas.

Conducted a post-project review of UPRR bridge abutment removal sites with UPRR equipment contractor on Wildhorse Creek between RM 2 and RM 12.

Coordinated with the Oregon Department of Transportation and ODFW to discuss potential mitigation/restoration of the Greasewood Creek stream channel near Helix.

Provided a display and literature at the Umatilla Basin Ecosystem Forum.

Participated in Umatilla River Basin Regulatory Work Group Meetings with ODSL, COE. other commenting agencies and the public. The focus of this group is to provide technical assistance to landowners before submitting permit applications, provide a more streamlined permit review process for landowners and to address instream activities on a reach by reach basis (to discourage unnecessary detrimental instream practices). CTUIR participated not only because of our role as a commenting agency, but also to address detrimental instream practices impacting watershed health. 


\section{Scoping Groups:}

Initial scoping meetings were conducted during the 1993 - 94 work period to identify landowners, sportsman clubs, special interest groups and resource agencies to assist in identification of problems areas in major subwatersheds and in development of long term innovative methods of improving detrimental land use practices impacting fisheries habitat. Additional scoping meetings were conducted during the 1994 - 95 project period to receive input from landowners regarding specific subbasins in which to focus implementation efforts and to appraise participants of ongoing CIUIR Habitat Enhancement Project efforts.

After careful review of the input received from scoping group participants, the Mission Creek Watershed was chosen over several other upper Umatilla River Basin subwatersheds because of the following determinations:

1) Mission Creek, a 3.100 acre watershed, is an ideal size for a watershed demonstration project; momentum gained in the watershed may carry into neighboring subwatersheds (Coonskin, Moonshine and Cottonwood);

2) the watershed is comprised of a variety of land uses including residential, rangeland, cropland, CRP lands and abandoned croplands;

3) landowners in the watershed appear to be supportive of watershed restoration efforts; nearly one-third of the watershed is comprised of croplands owned by landowners participating in the Highly Erodible Lands (HEL) Program and/or enrolled under the CRP;

4) the system has potential for anadromous and resident fish populations; juvenile coho salmon have been sampled in Mission Creek, and Tribal members report significant rainbow trout populations in past decades when the stream carried year-round stream flows.

A scoping meeting was conducted on the evening of June 20, 1995 in the Yellowhawk Clinic Conference Room on the Reservation to familiarize Mission Creek Watershed landowners with restoration/management improvements. which have been successful in other watersheds, and to receive their input regarding potential implementation of such improvements in the Mission Creek Drainage. BIA, NRCS and CTUIR provided presentations regarding range, cropland and riparian/stream habitat improvements. While scoping group participants overall appeared supportive of the process, several indicated that they believed good conservation measures were currently being implemented in the watershed and 
doubted that significant salmonid populations had ever occurred in Mission Creek. Twenty-five people attended the scoping meeting. Eleven of the people present were landowners in the subbasin; the remainder were resource agency personnel.

Future scoping meetings will be held to obtain additional landowner input, to provide baseline data/findings to participants and to solicit support for potential watershed improvement projects.

\section{Public Education Opportunities:}

The CTUIR Habitat Enhancement Project provided a variety of educational opportunities to the public during the project period. CTUIR cooperatively sponsored a watershed restoration workshop with the Native American Fish \& Wildlife Society on December 14 and 15, 1995. The watershed restoration workshop featured 7 speakers, including the CTUIR Habitat Enhancement Project Leader. and attracted a combined total of 85 participants over the two day period. Presentations included information on the following: 1) Tribal watershed restoration perspectives, 2) integrated management, 3) hydrology and soils, 4) landowner conservation programs and funding opportunities, 5) project planning and preparation, 6) project implementation and monitoring, 7) native plant communities, 8) native plant physiology, collection and propagation, and 9) an overview of native plant materials and planting methods. The second day of the workshop provided participants with the opportunity to learn specific bioengineering techniques and apply these techniques in a field setting. Bioengineering treatments were implemented in the Wildhorse Creek Project Area. Assorted watershed restoration/management literature was made available to those attending the workshop.

The purpose of this workshop was to provide information to land owners, resource agencies and Tribal Salmon Corps crews for planning, designing and implementing watershed restoration/habitat enhancement projects. A free reference notebook was given to each participant.

A five day native revegetation/bioengineering training contract was issued to Tree of Life Nursery on April 10, 1996 to train Umatilla Salmon Corps Members how to: 1) identify and collect native plant materials, 2) identify potential restoration sites, and 3) utilize various bioengineering techniques to install native plant materials. These individuals were trained to provide assistance to CTUIR Habitat Enhancement Project Personnel with revegetation efforts in riparian corridor areas.

Additional public education opportunities provided during the 1995 - 96 project period are listed on pages 29 \& 30 under Objective III.. 1. Community Outreach Effort.

\section{4. public Monitoring Programs:}


High school students, tribal youth, scoping group participants and others were encouraged to develop long term community stream monitoring programs (such as the EPA Region 10 Streamwalk Program). These efforts were directed at promotion of citizen involvement, ownership and commitment to watershed health.

\section{Educational Brochure:}

Design of a brochure to highlight successful CIUIR riparian enhancements in the Umatilla River was started during the 1994 - 95 project period. CIUIR did not continue development of the brochure into the 1995 - 96 project period. It was determined funds would be better utilized to produce visual watershed education displays. A total of 99 photographic enlargements and labels were developed to illustrate watershed/habitat impacts and various improvement practices. These displays will serve as educational tools at various workshops, conferences and public meetings. CTUIR will again pursue production of an educational brochure in the near future.

Objective IV. Pursue Alternative Management Methods to Mitigate Impacts from Past and Ongoing Land Management Activities:

1. Acquisition Land/Management Rights:

A 560 acre property was identified for potential purchase in the upper Eagle Creek Watershed. This small watershed is a tributary to upper Wildhorse Creek and is located entirely within Reservation Boundaries. The property currently maintains perennial stream flows and is comprised of cropland and rangeland. Rangeland areas have remained ungrazed for the past 3 years. This drainage is not documented as supporting anadromous fish and is unlikely to be utilized by anadromous fish in the near future. However, because this is a headwater property located in a watershed which currently contributes significant sediment loads into the Umatilla River, acquisition and protection of this property would prove beneficial. Acquisition of this property would be consistent with current top down, watershed restoration approaches. CTUIR Habitat Enhancement Project Personnel coordinated with CIUIR Wildlife Program Personnel during the project period regarding potential acquisition of this property. 


\section{LITERATURE CIIED}

Adehnan, Bob. January 11, 1996. Personal Comment stated at Mission Creek Watershed Coordination Meeting.

Bell. M.C. 1984. Fisheries Handbook of Engineering Requirements and Biological Criteria. Fish Passage Development and Evaluation Program, U.S. Army Corps of Engineers, North Pacific Division. Portland, Oregon.

Campbell, I.C., K.R. James and RT. Edwards. Farming and Streams - Impact, Research and Management. Proc. of the Conference, The State of Our Rivers, Australia Natural History, September 1990 (as cited by Gordon, N.D., TA. McMahon and B.L Finlayson, 1993).

Confederated Tribes of the Umatilla Indian Reservation. 1983. Land Development Code, Land Use Map of the Umatilla Indian Reservation Land Development Code. Pendleton, Oregon. $186 \mathrm{p}$.

Elmore, W. and R.L. Beschta. 1987. Riparian Areas: Perceptions in Management. Rangelands 9(6) 260 - 265 (as cited by Bauer, S.B. and TA. Burton).

Gonthier. J.B. and D.D. Harris. 1977. Water Resources of the Umatilla Indian Reservation, Oregon. USGS Water Resources Investigations 77-3. U.S. Geological Survey, Portland, Oregon. 112 p.

Gordon, N.D., T.A. Mcmahon and B.L. Finlayson. 1993. Stream Hydrology - An Introduction for Ecologists. John Wiley \& Sons Ltd., New York, New York 526 p.

Lambert, S.M., A. Sassman and J. Rouse. 1995. Washington and Oregon Conservation Grasses, Wildflowers, Legumes, Trees, and Shrubs. Natural Resource Conservation Service. Spokane, Washington. 67 p.

Meyers, L.H. 1987. Montana BLM Riparian Inventory and Monitoring, Riparian Technical Bulletin No. 1.. BLM-MT-PT-88-001-4410, Billings, MT (as cited by Bauer, S.B. and TA. Burton).

Trout Unlimited. 1994. The Invisible Menace - Agricultural Polluted Run-off in our Nation's Streams. 12 p.

U.S. Army Corps of Engineers, Walla Walla District. 1975. Flood Plain Information, Umatilla River Cayuse - Gibbon, Oregon. 22 p.

USDA, Forest Service - Intermountain Region Wildlife Management. 1985. Aquatic Ecosystem Inventory - Macroinvertebrate Analysis, Chapter 5 Aquatic Macroinvertebrate Surveys "from” Fisheries Habitat Surveys Handbook R-4 FSH 2609.23. Provo, Utah. 38 p. 
USDA, Soil Conservation Service. 1988. Soil Survey of Umatilla County Area, Oregon. U.S. Gov. Printing Office 19880 - 183-557. 388 p.

U.S. Fish and Wildlife Service and National Marine Fisheries Service. 1981. Eastern Oregon Anadromous Fish Habitat Restoration Project. Portland, Oregon.

Wilson, Ray. June 26, 1996. Personal Comment from phone conversation. 
Appendix A

Water Temperature Graphs 


\section{UMATILLA RIVER}

River Mile 78.5 (Downstream Mouth of Meacham Creek)

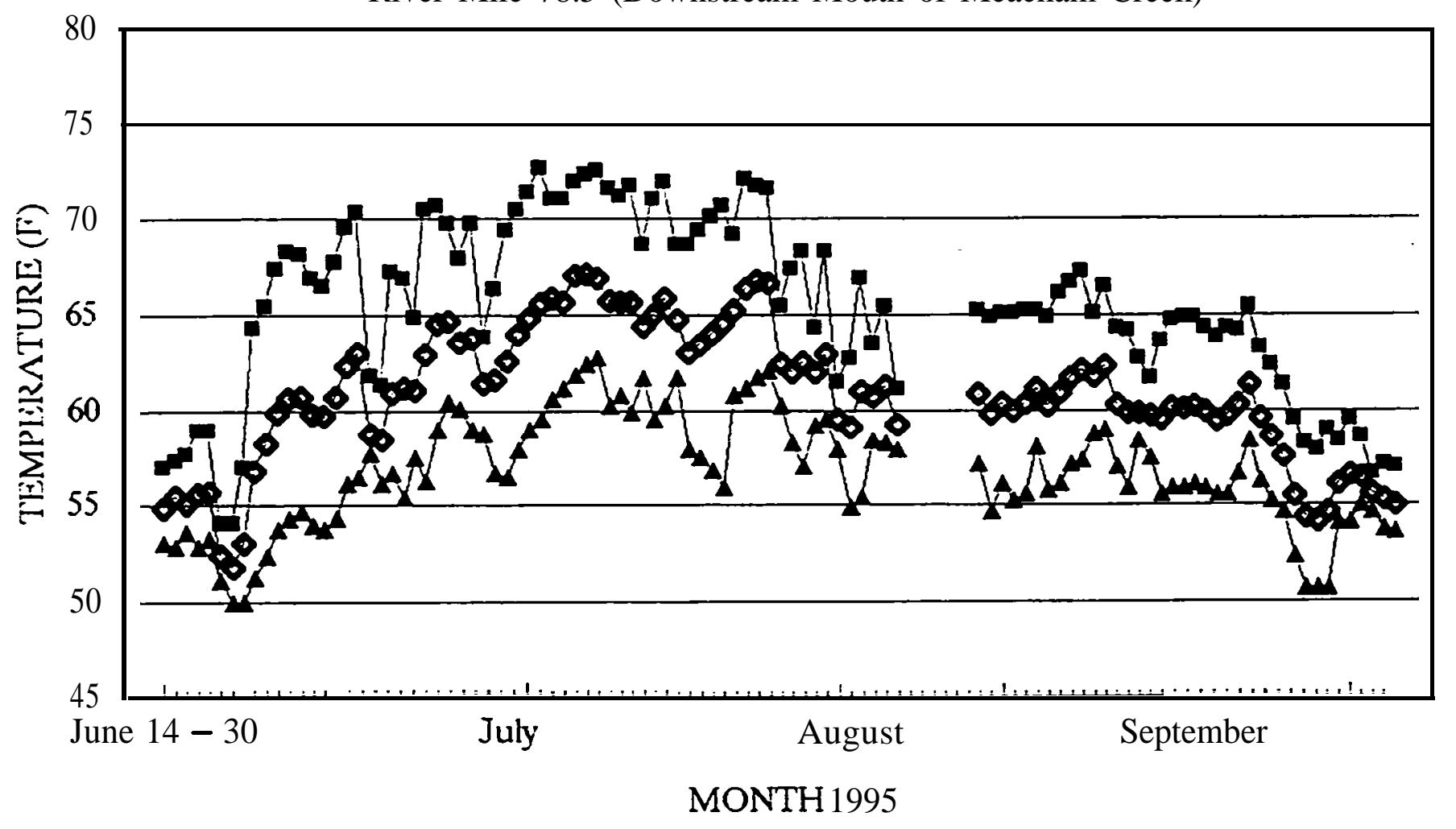

$\rightarrow-$ Maximum $\rightarrow$ Minimum $\multimap$ Average

File Same: UMRM7895; Graph File Name: UMAR7895

Data unavailable June 1-13, 1995 and August $18-23,1995$ (instrument out of water) 


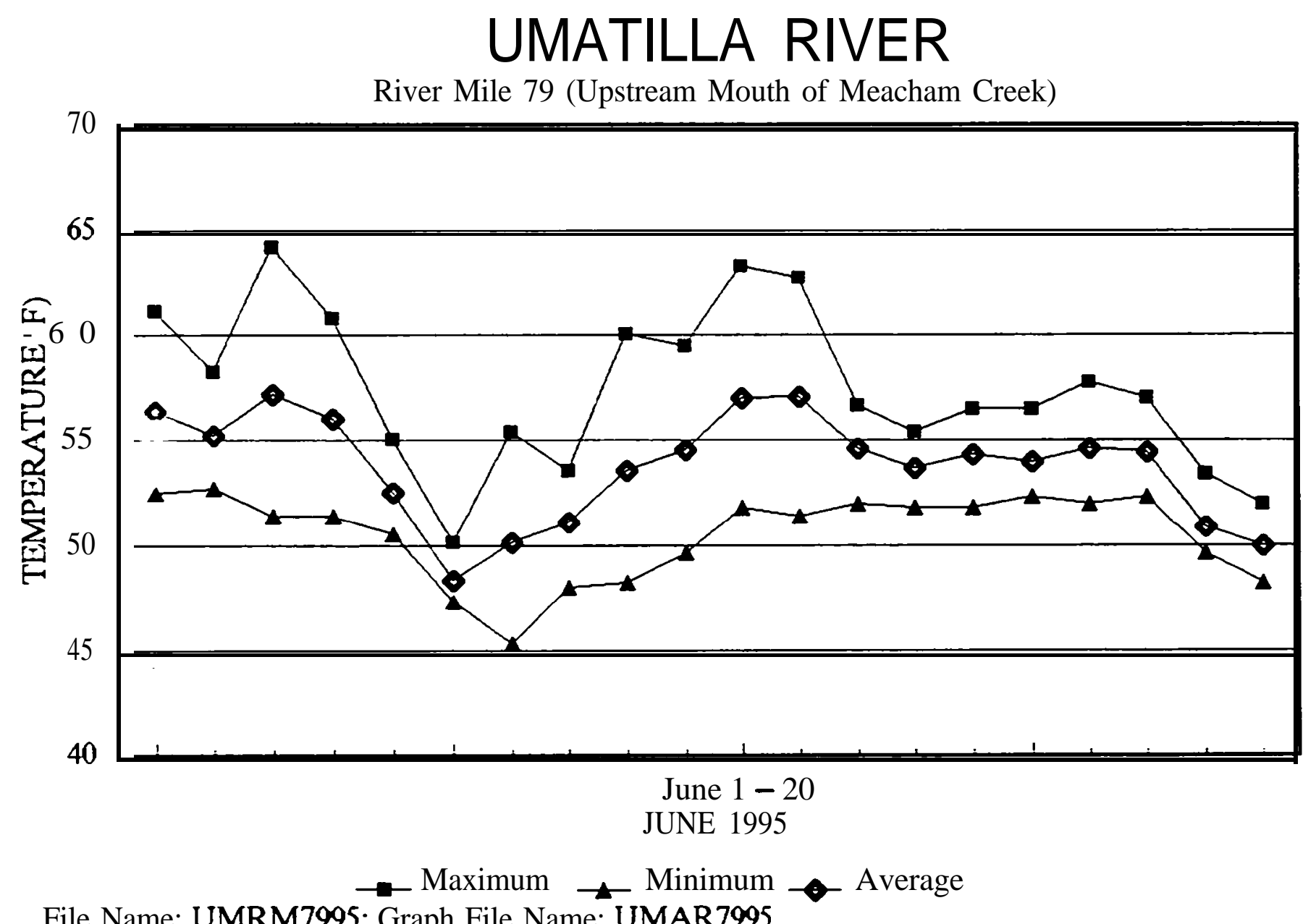

File Name: UMRM7995; Graph File Name: UMAR7995

Data unavailable for late June, July, August and September 1995 due to instrument being lost in high 


\section{UMATILLA RIVER}

River Mile 81.7 (USGS Gage Station 1402000)

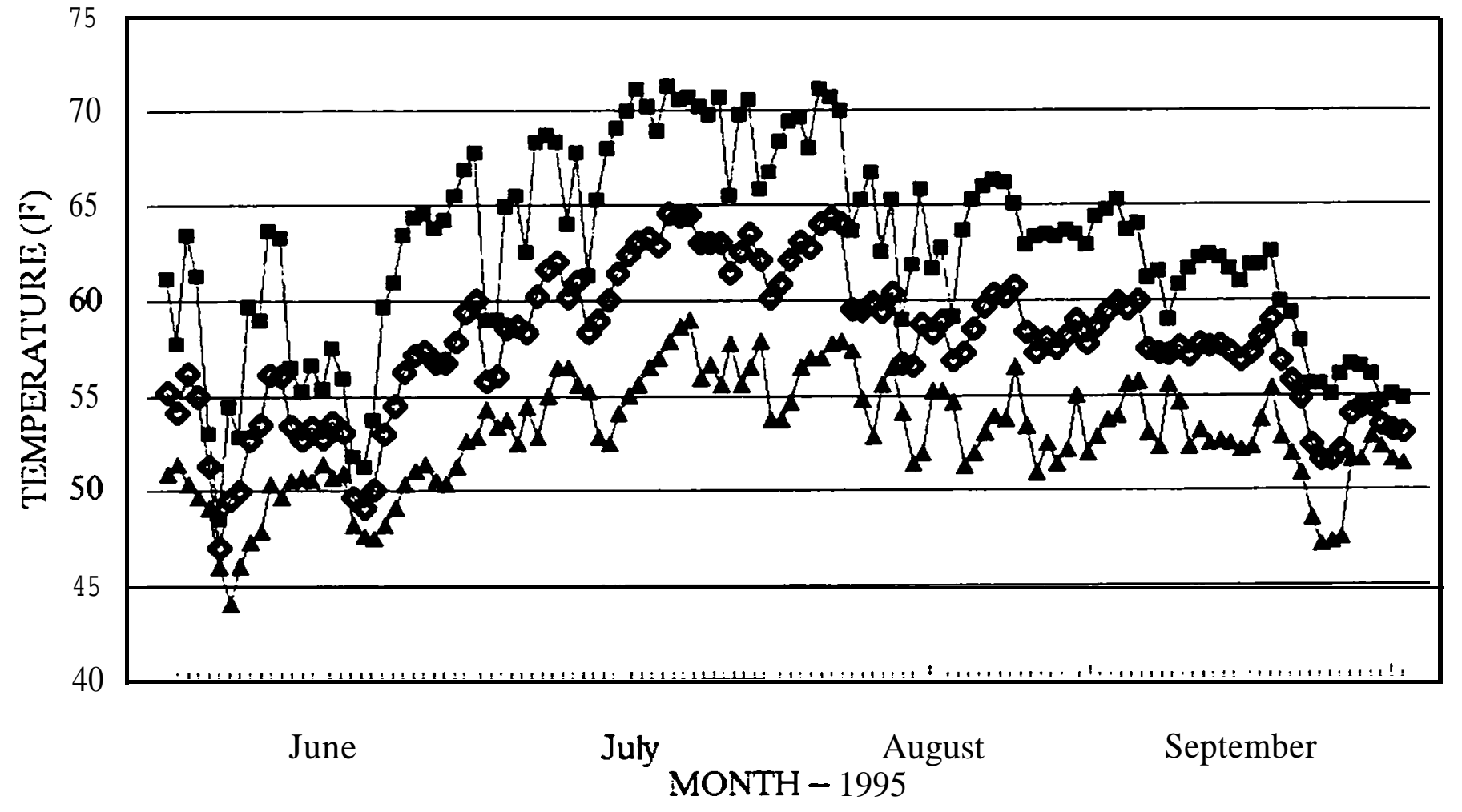

File Name: UMRM8195

Graph File Name: UMAR8195 


\section{WILDHORSE CREEK}

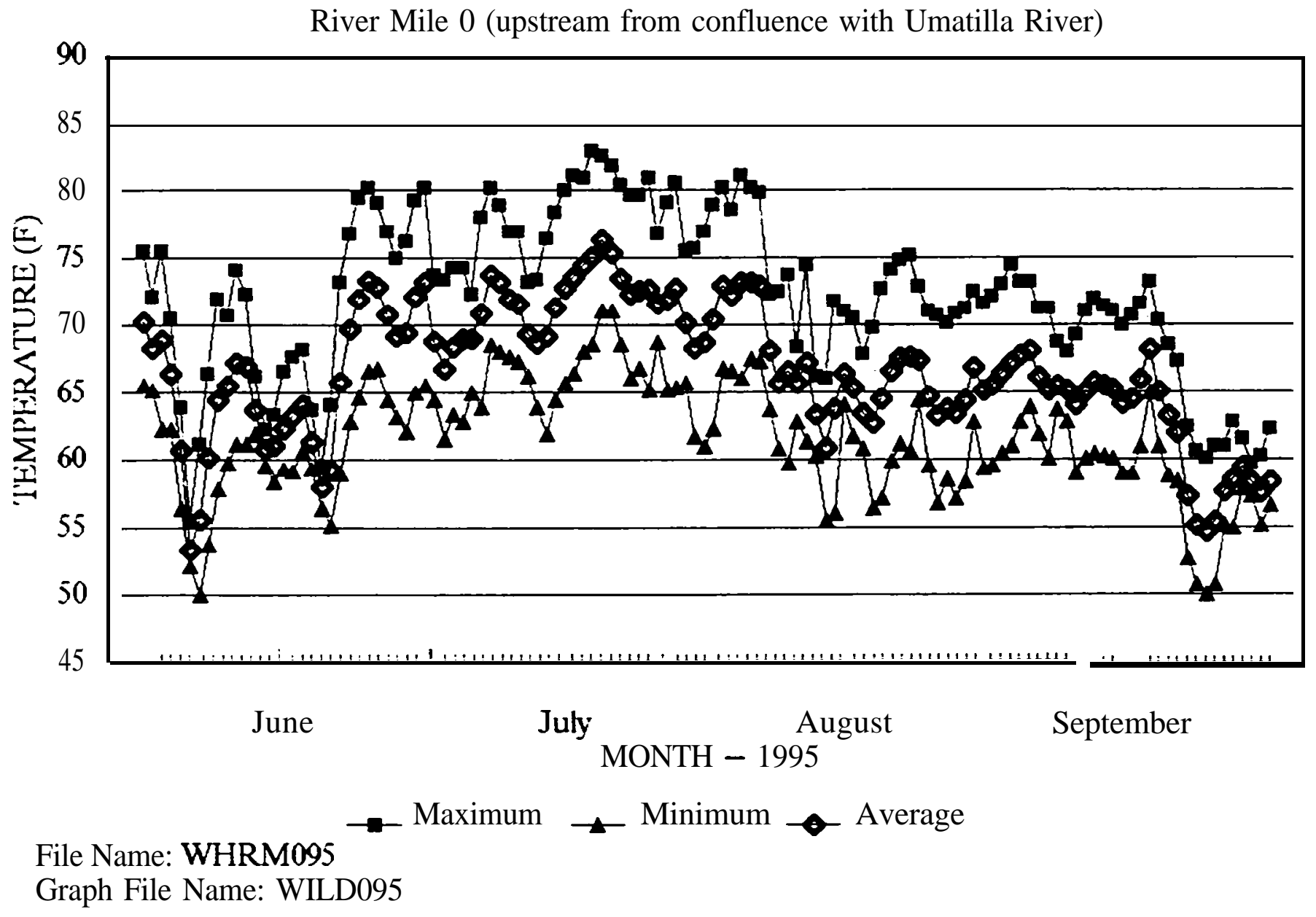




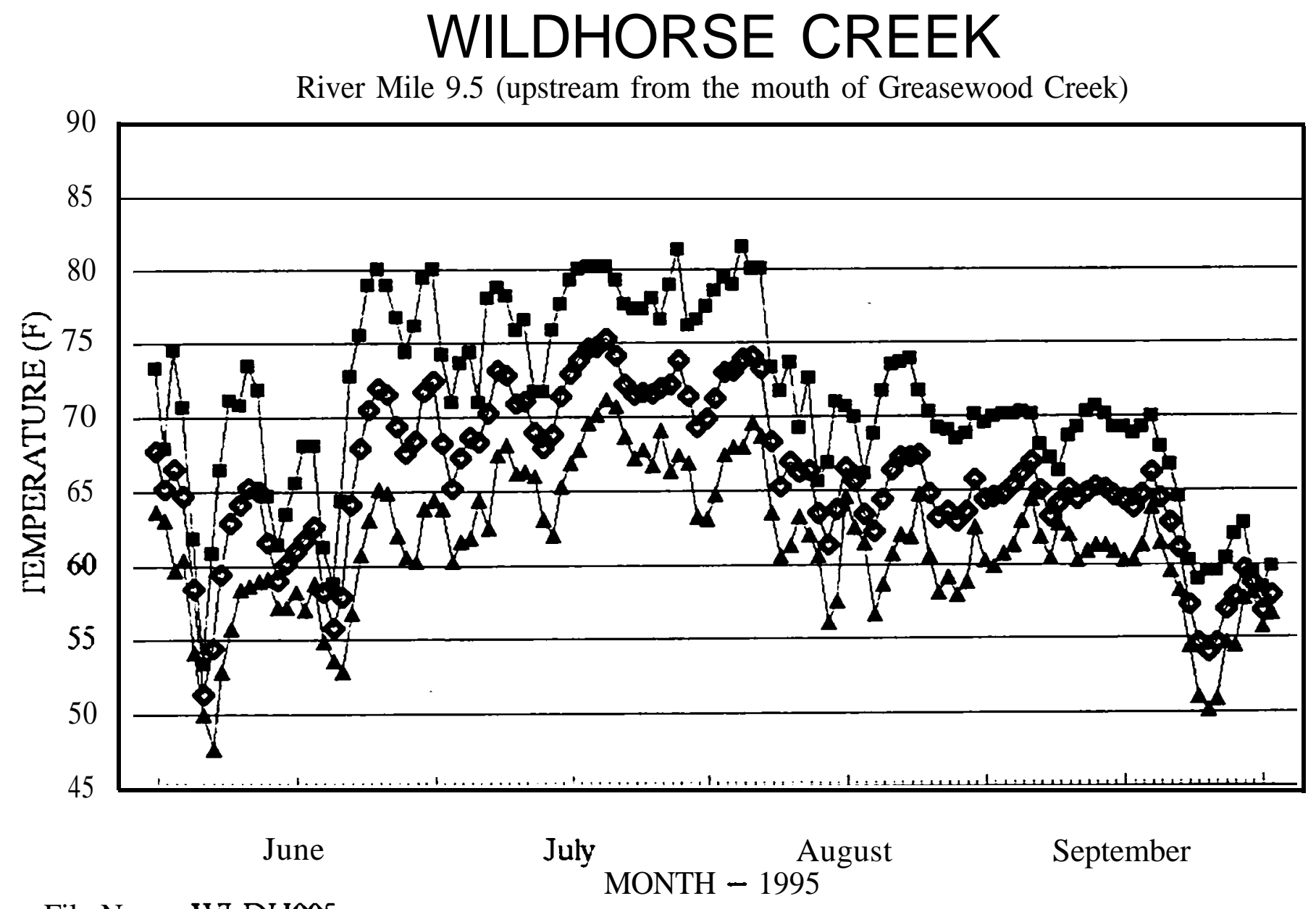

File Name: WLDH995

Graph File Name: WHRM995 







\section{MISSION CREEK}

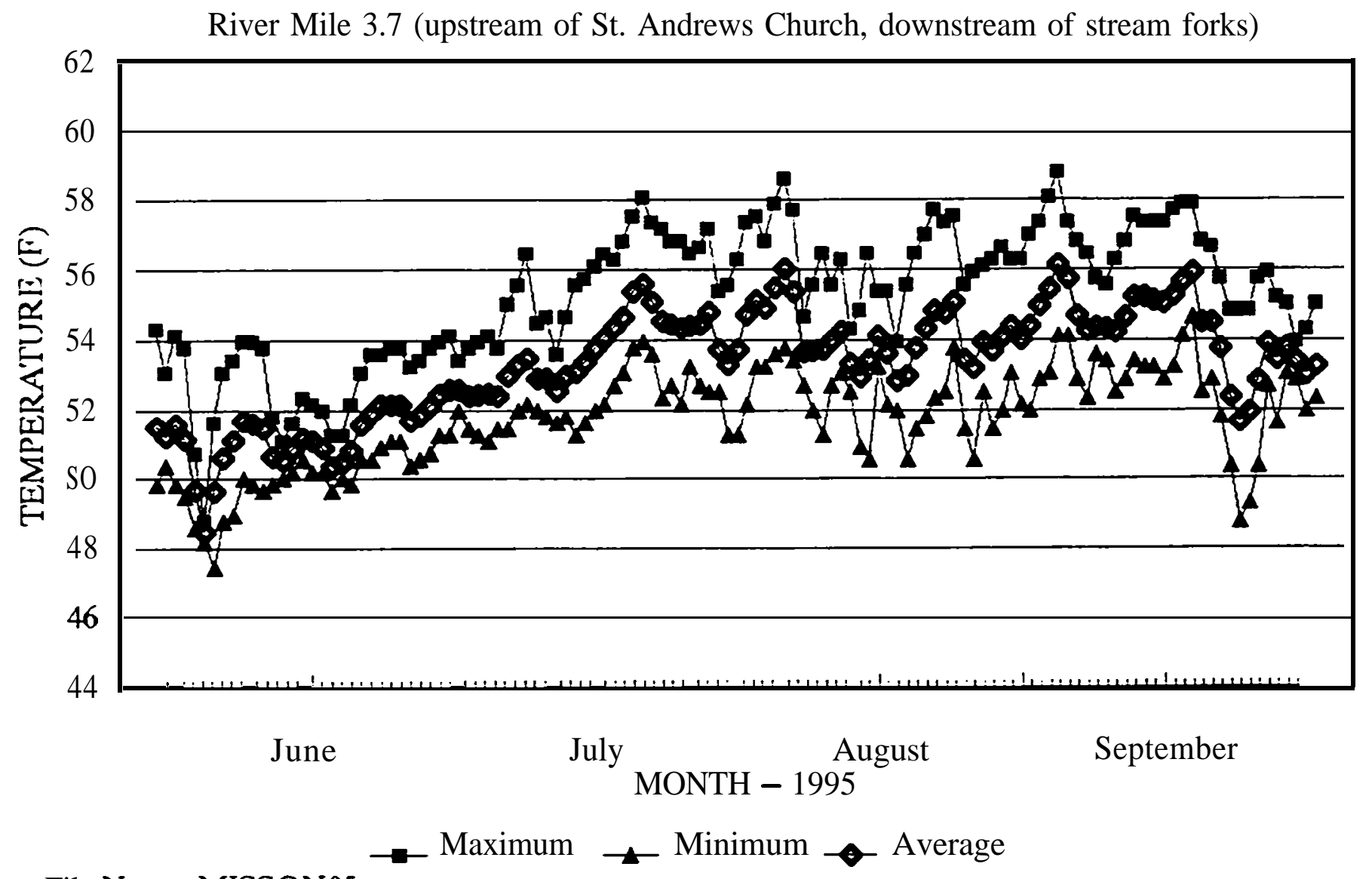

File Name: MISSON95

Graph File Name: MSSTAN95 


\section{BUCKAROO CREEK}

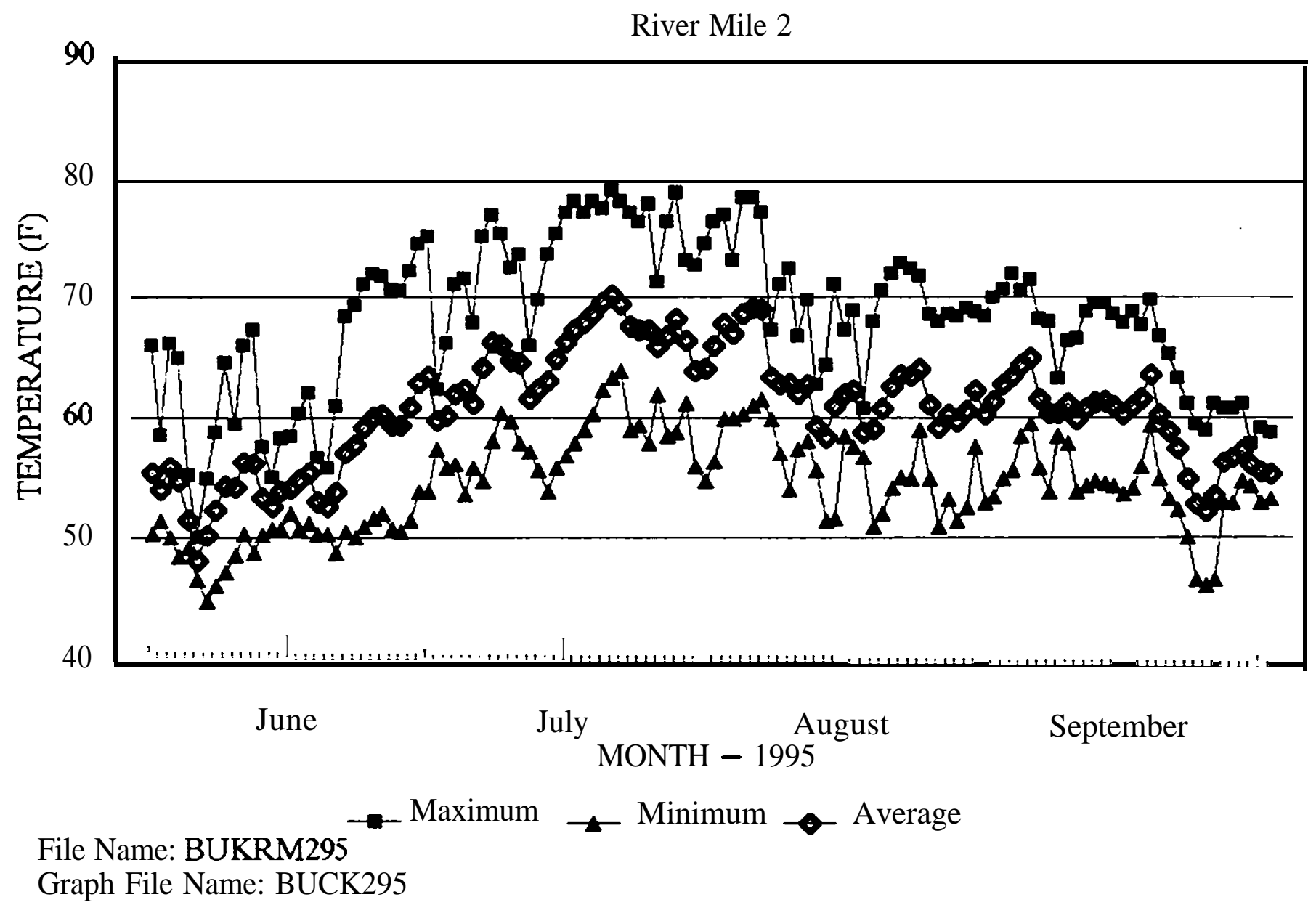




\section{SQUAW CREEK}

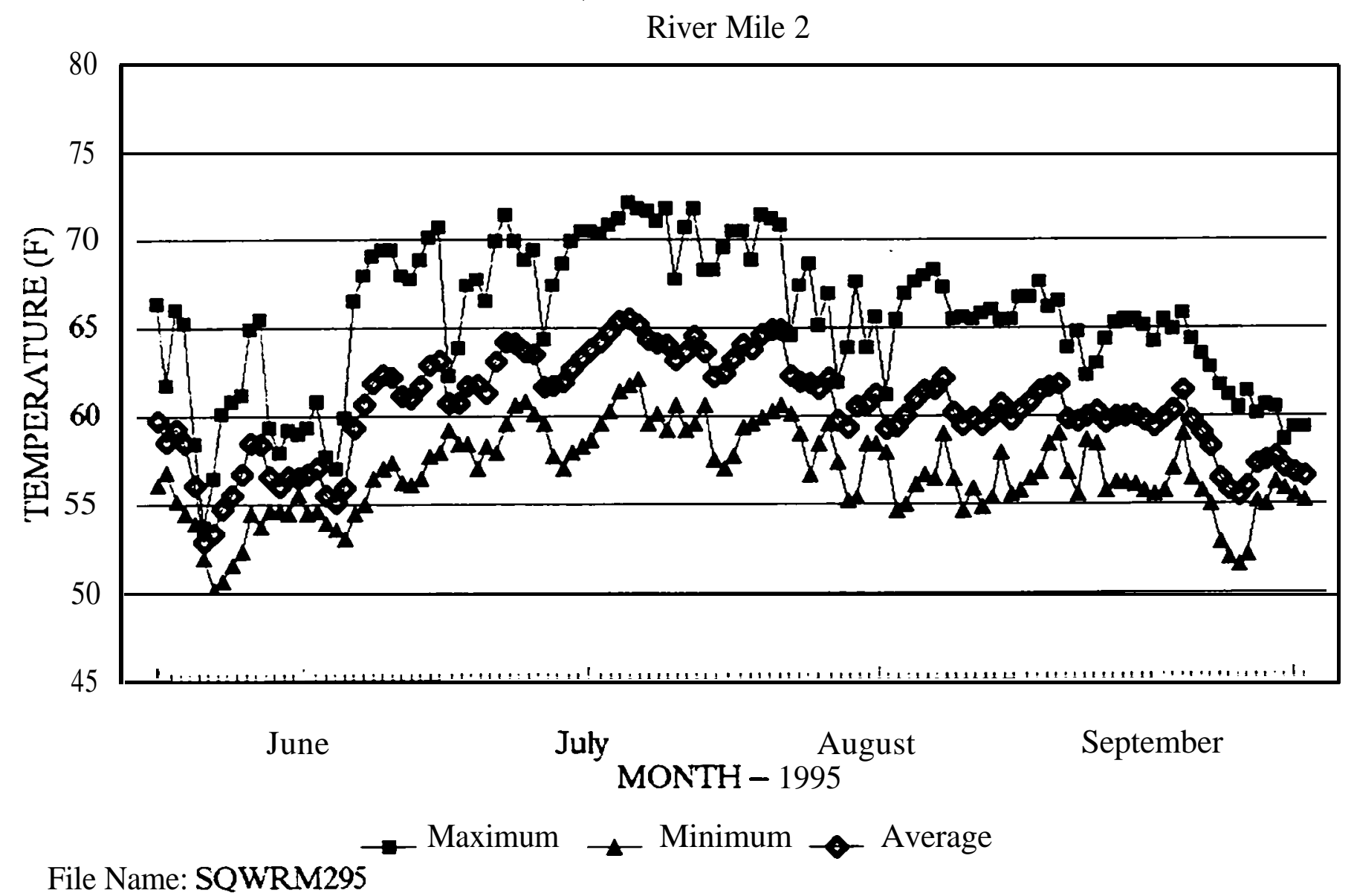

Graph File Name: SQUAW295 







\section{MEACHAM CREEK}

River Mile 2 (USGS Gage Station No. 14020300)

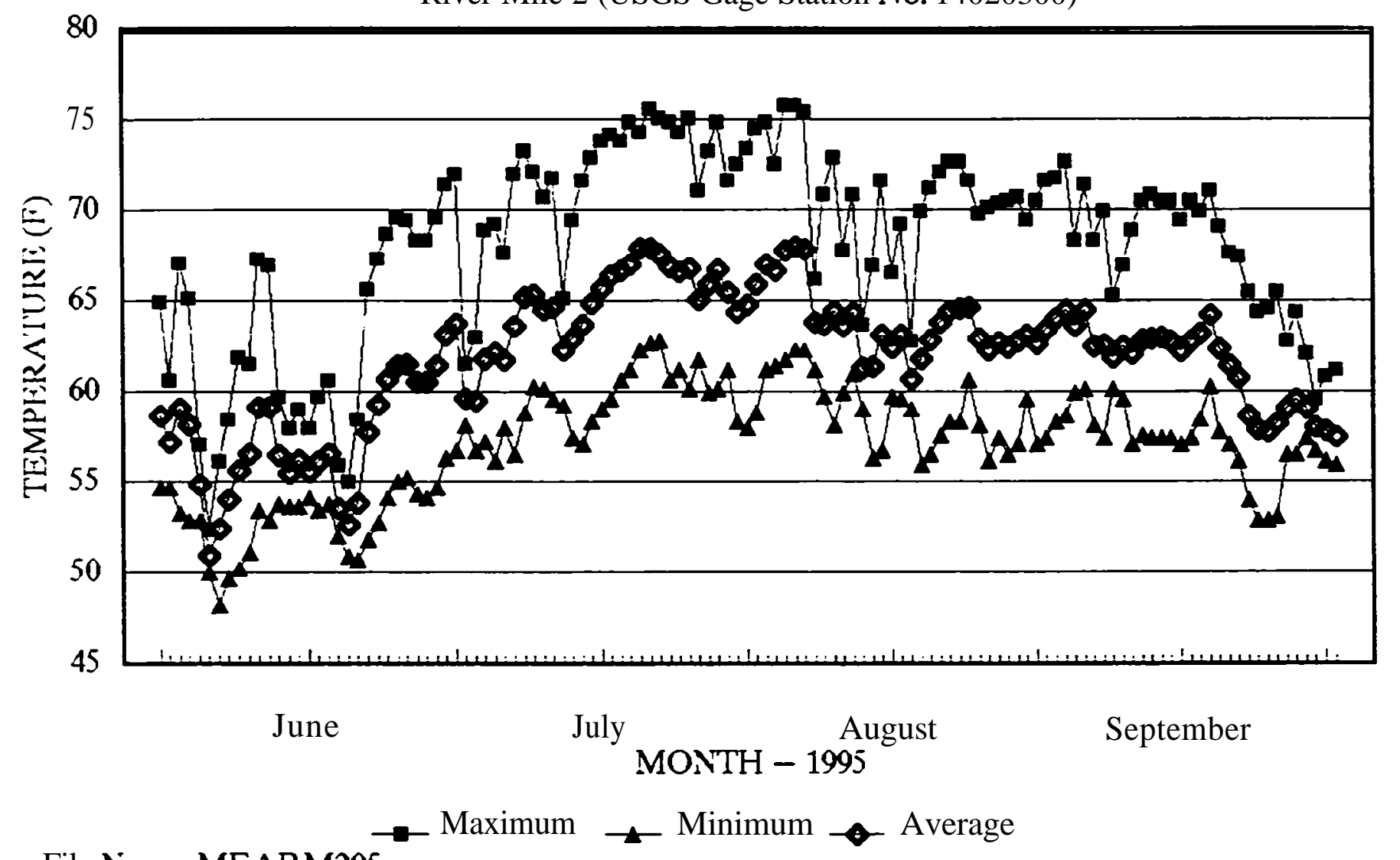

File Name: MEARM295

Graph File Name: MEACH295 





Appendix B

Suspended Sediment Graphs 


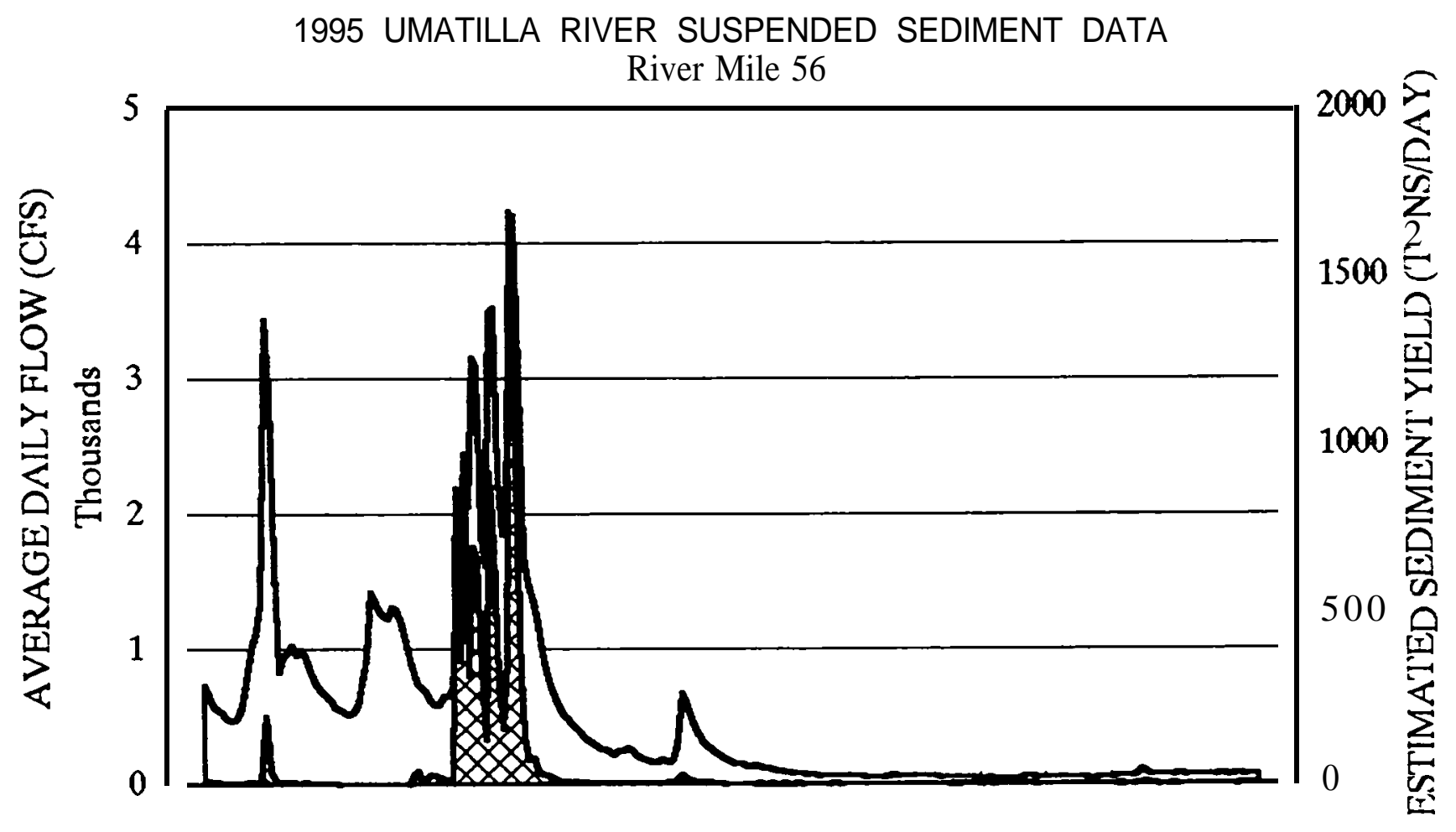

MAR APR MAY JUNE JULY AUG SEPT OCT MONTH

Flow (CFS)

Estimated Sediment Load (Tons/Day)

File Name: USED5695; Graph File Name: U5695SED

Sediment data unavailable April 1 - 17, 1995 


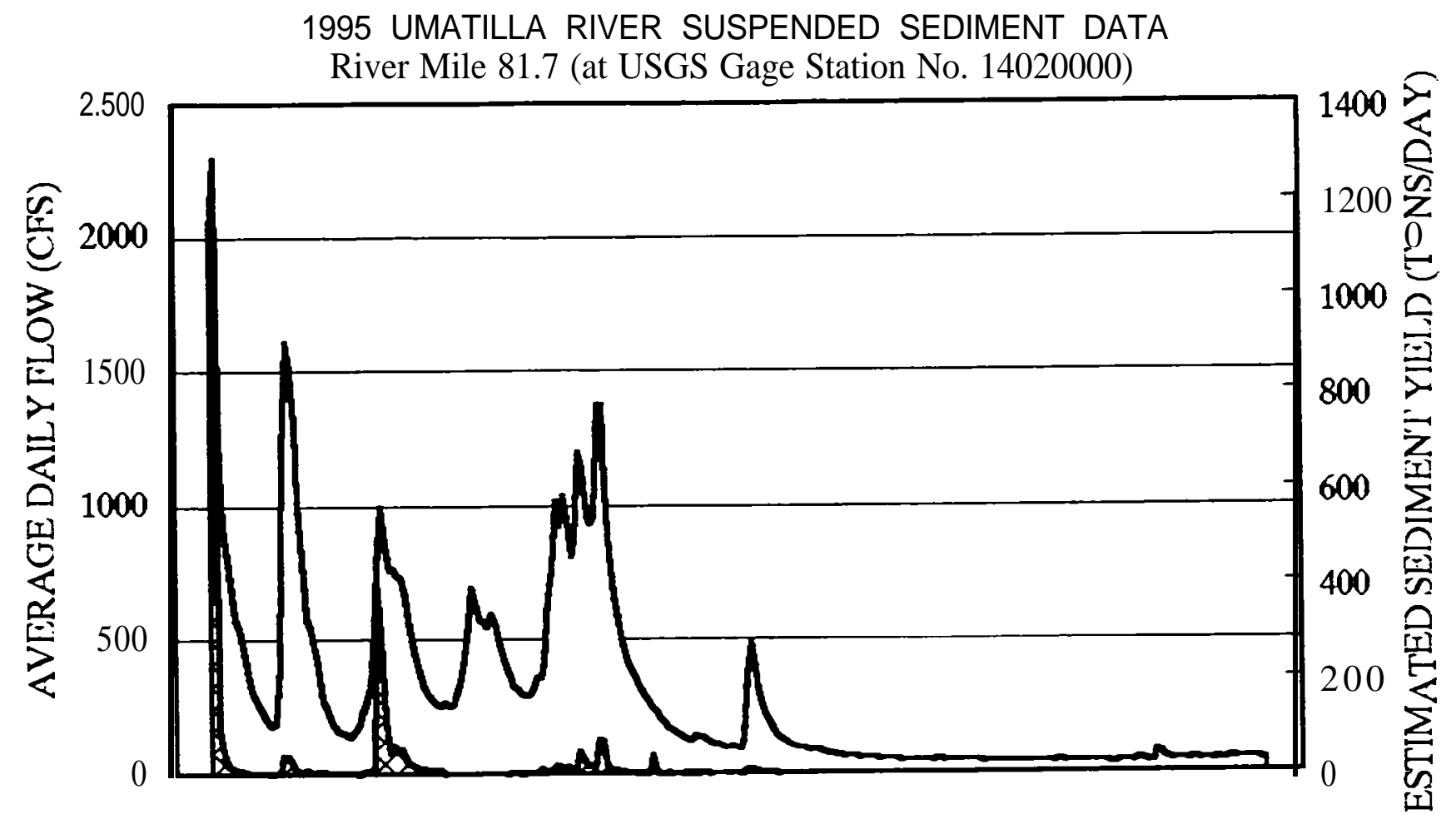

FEB MAR APR MAY JUNE JULY AUG SEPT OCT MONTH

$\square$ Flow (CFS) Estimated Sediment Load (Tons/Day)

File Name: USED8195; Graph File Name: 95SEDU81

Sediment data unavailable April 1 - 17, 1995 


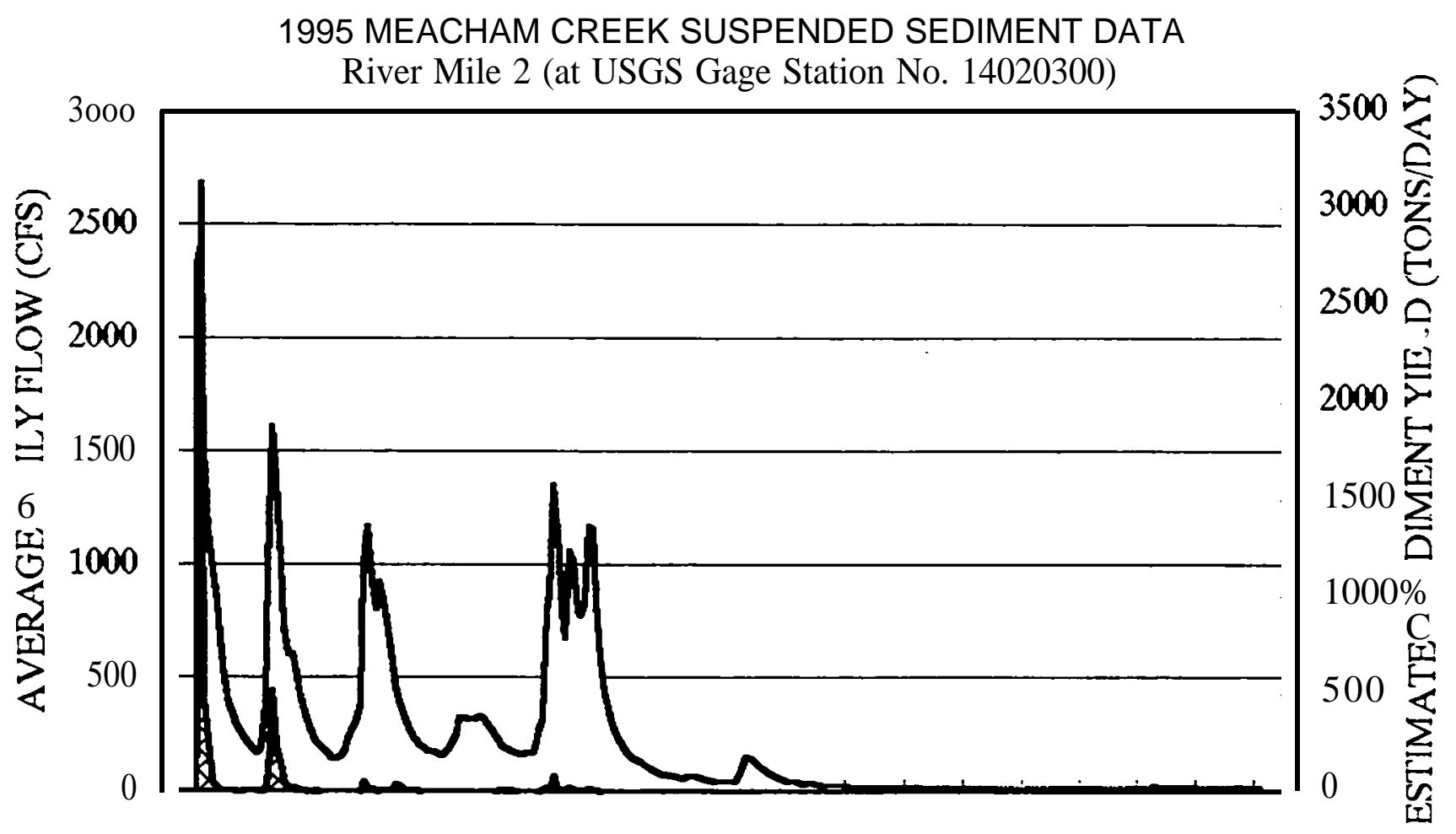

FEB MAR APR MAY JUNE JULY AUG SEPT OCT MONTH

Flow (CFS)

Estimated Sediment Load (Tons'Day)

File Name: MCSED295; Graph File Name: 95MCSED2

Sediment data unavailable April 1 - 17, 1995 